\title{
The Influence of Temperature and Community Structure on Light Absorption by Phytoplankton in the North Atlantic
}

\author{
Robert J. W. Brewin ${ }^{1,2, *}$ ) , Stefano Ciavatta ${ }^{2,3}$, Shubha Sathyendranath ${ }^{2,3}$, Jozef Skákala ${ }^{2,3}$, \\ Jorn Bruggeman ${ }^{2}$, , David Ford ${ }^{4}$ and Trevor Platt ${ }^{2}$ \\ 1 College of Life and Environmental Sciences, University of Exeter, Penryn Campus, Cornwall TR10 9FE, UK \\ 2 Plymouth Marine Laboratory, Plymouth, Devon PL1 3DH, UK; avab@pml.ac.uk (S.C.); ssat@pml.ac.uk (S.S.); \\ jos@pml.ac.uk (J.S.); jbr@pml.ac.uk (J.B.); tplatt@dal.ca (T.P.) \\ 3 National Centre for Earth Observation, Plymouth Marine Laboratory, Plymouth, Devon PL1 3DH, UK \\ 4 Met Office, Exeter, Devon EX1 3PB, UK; david.ford@metoffice.gov.uk \\ * Correspondence: r.brewin@exeter.ac.uk; Tel.: +44-1326-255119
}

Received: 17 July 2019; Accepted: 21 September 2019; Published: 26 September 2019

\begin{abstract}
We present a model that estimates the spectral phytoplankton absorption coefficient $\left(a_{p h}(\lambda)\right)$ of four phytoplankton groups (picophytoplankton, nanophytoplankton, dinoflagellates, and diatoms) as a function of the total chlorophyll-a concentration $(C)$ and sea surface temperature (SST). Concurrent data on $a_{p h}(\lambda)$ (at 12 visible wavelengths), $C$ and SST, from the surface layer $(<20 \mathrm{~m}$ depth) of the North Atlantic Ocean, were partitioned into training and independent validation data, the validation data being matched with satellite ocean-colour observations. Model parameters (the chlorophyll-specific phytoplankton absorption coefficients of the four groups) were tuned using the training data and found to compare favourably (in magnitude and shape) with results of earlier studies. Using the independent validation data, the new model was found to retrieve total $a_{p h}(\lambda)$ with a similar performance to two earlier models, using either in situ or satellite data as input. Although more complex, the new model has the advantage of being able to determine $a_{p h}(\lambda)$ for four phytoplankton groups and of incorporating the influence of SST on the composition of the four groups. We integrate the new four-population absorption model into a simple model of ocean colour, to illustrate the influence of changes in SST on phytoplankton community structure, and consequently, the blue-to-green ratio of remote-sensing reflectance. We also present a method of propagating error through the model and illustrate the technique by mapping errors in group-specific $a_{p h}(\lambda)$ using a satellite image. We envisage the model will be useful for ecosystem model validation and assimilation exercises and for investigating the influence of temperature change on ocean colour.
\end{abstract}

Keywords: phytoplankton absorption; community structure; temperature; North Atlantic

\section{Introduction}

Light absorbed by phytoplankton is either converted to heat or used in photosynthesis. The conversion to heat helps modulate the physical structure of the ocean's surface layer [1,2]. Photosynthesis converts inorganic to organic carbon, modifying the $\mathrm{CO}_{2}$ concentration and $\mathrm{pH}$ of the water, and providing energy to roughly half of the life on our planet. Consequently, light absorption by phytoplankton plays an important role in the functioning of the ocean.

The phytoplankton absorption coefficient $\left(a_{p h}(\lambda)\right.$, where $\lambda$ is the wavelength of light), is used to represent the amount of light absorbed by phytoplankton per unit length. It is a fundamental quantity in physical and biogeochemical ocean models, altering underwater spectral light transmission [3-6] and the photosynthetic response of phytoplankton to available light [7-9]. The magnitude and 
spectral shape of $a_{p h}(\lambda)$ are controlled by phytoplankton biomass, size and type. Consequently, routine measurements of $a_{p h}(\lambda)$ are used to monitor the amount, composition and size structure of phytoplankton in aquatic systems [10-16].

Historically and conventionally, $a_{p h}(\lambda)$ has been modelled as a function of the total chlorophyll-a concentration $(C$, representing the sum of mono- and divinyl-chlorophyll-a, chlorophyllide-a, and the allomeric and epimeric forms of chlorophyll-a), the main photosynthetic pigment in all phytoplankton and a measure of phytoplankton biomass. Nonlinearity in this relationship, which varies with wavelength, is indicative of changes in phytoplankton size and pigment composition [17-22]. Empirical models that derive $a_{p h}(\lambda)$ from $C$ have been proposed, including: power-law functions [22-27]; hyperbolic tangent functions [28]; polynomial functions [29]; and Michaelis-Menten-type functions [6,30].

Theoretical approaches have also been proposed, for example, those that express $a_{p h}(\lambda)$ as the contribution of different populations of phytoplankton in the water [10,14,31-33], such that $a_{p h}(\lambda)$ can take the form

$$
a_{p h}(\lambda)=\sum_{i=1}^{N} a_{i}^{*}(\lambda) C_{i}
$$

where $i$ is the population, $N$ is the number of different populations, $a_{i}^{*}(\lambda)$ is the chlorophyll-specific absorption coefficient for population $i$, and $C_{i}$ is the chlorophyll-a concentration for population $i$ (Table A1 in the Appendix to this manuscript defines all symbols used). Unlike empirical models [30], the parameters of Equation (1) have clear interpretation and the approach ensures plausible values of $a^{*}(\lambda)$ at extreme chlorophyll-a concentrations, since the range of values of $a^{*}(\lambda)$ is bounded by the values associated with the populations. Models with two [32] and three [14,31,33] populations have been proposed, typically partitioning populations of phytoplankton according to size ranges, since $a^{*}(\lambda)$ is known to change with cell size [10].

Approaches have also been proposed that tie changes in $C_{i}$ with $C$ [32,34], meaning that $a_{p h}(\lambda)$ can be derived from Equation (1) as a function of $C$, by relating $C_{i}$ to $C$, if a priori information exists on $a_{i}^{*}(\lambda)[14,31,32]$. It is widely recognised that temperature is a useful variable for predicting phytoplankton community structure [35-44] and consequently, $a^{*}(\lambda)$ [45]. Recently, Brewin et al. [46] proposed a model that estimates $C_{i}$ for four populations of phytoplankton (picophytoplankton, nanophytoplankton, dinoflagellates, and diatoms) as a function of $C$ and sea surface temperature (SST) in the North Atlantic, both of which can be retrieved through satellite remote sensing. The approach has proven useful for satellite data assimilation into multi-phytoplankton ecosystem models [47,48], although assimilating the optical properties of the phytoplankton groups directly (i.e., $a_{p h, i}(\lambda)$ rather than $C_{i}$ ) could be more beneficial [49].

In this paper, using the approach of Brewin et al. [46], we extend the three-population absorption model of Brewin et al. [31] to four populations of phytoplankton. Our purposes for developing this new model were twofold: (1) to estimate $a_{p h}(\lambda)$ for four phytoplankton groups (dinoflagellates, diatoms, nanophytoplankton, and picophytoplankton) that match those simulated in a state of the art marine ecosystem model (the European Regional Seas Ecosystem Model, ERSEM), using remotely-sensed input ( $C$ and SST), and quantify uncertainties in these estimates for use in a future optical data-assimilation experiment using ERSEM; and (2) investigate how temperature change may influence ocean colour in the context of climate change.

The new model yields total and population-specific $a_{p h}(\lambda)$ as a continuous function of $C$ and SST. Data from the North Atlantic containing $a_{p h}(\lambda), C$ and SST measurements are separated into parameterisation and validation data. The parameterisation data are used to yield $a_{i}^{*}(\lambda)$ values for each of the four populations, which are subsequently compared with results from earlier studies. The performance of the model, when used to retrieve $a_{p h}(\lambda)$ for a given total chlorophyll concentration, is compared with those of two other models (a power-law model and a three-population model) using the independent validation data. An error-propagation method is proposed to quantify uncertainty in population-specific $a_{p h}(\lambda)$ derived from the four-population absorption model, and we integrate the 
four-population absorption model into a simple (case-1) model of ocean colour, to illustrate expected changes in the blue-to-green ratio of remote-sensing reflectance with changes in C and SST.

\section{Methodology}

\subsection{Study Area}

Our study area was the North Atlantic Ocean, spanning $100^{\circ} \mathrm{W}$ to $13^{\circ} \mathrm{E}$ and $20^{\circ} \mathrm{N}$ to $66^{\circ} \mathrm{N}$ (Figure 1). This region encompasses the Copernicus Marine Environment Monitoring Service (CMEMS) Ocean Colour Thematic Assembley Centre (OCTAC) Atlantic (ATL) region, the CMEMS Marine Forecasting Centre (MFC) of the North West Shelf-Seas (NWS) and Ireland-Biscay-Iberia (IBI) regions, as well as the north-west Atlantic and eastern seaboard of North America, covering a wide range of bio-optical environments, from the oligotrophic North Atlantic gyre through to shallower optically-complex shelf seas. The region has been sampled intensively over the past few decades, supports one of the largest spring phytoplankton blooms on the planet [50] and is a region of focus for many marine ecosystem modelling studies (e.g., [51]).

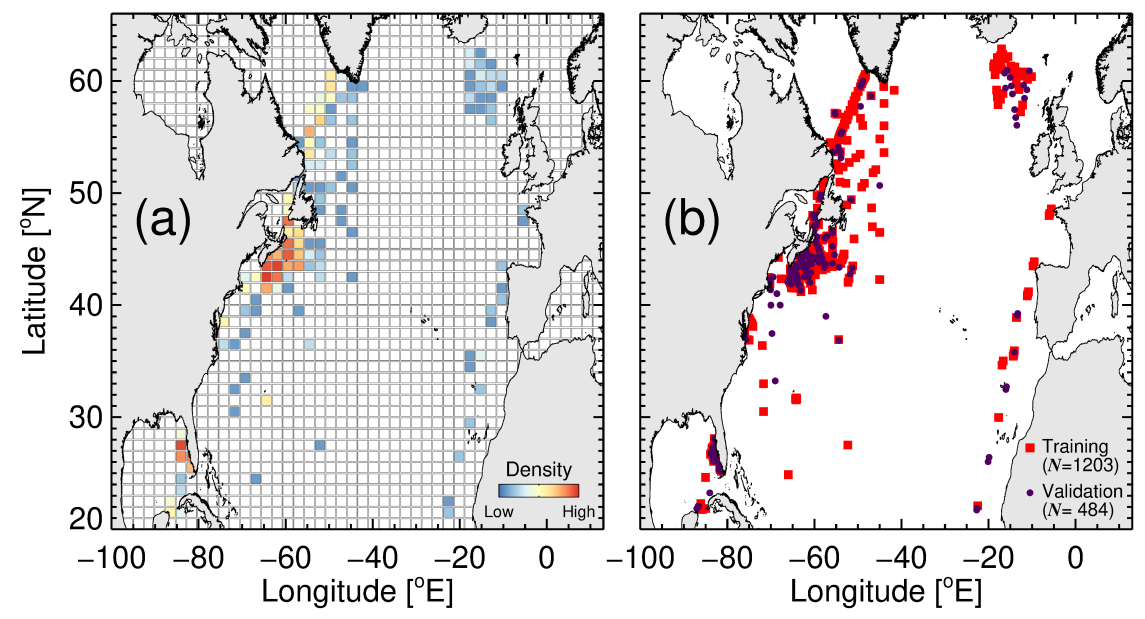

Figure 1. Study site and geographic distribution of the data used in the study. (a) Shows the spatial distribution of data used in the study, and (b) shows the partitioning into training and validation data.

\subsection{Data}

Two bio-optical datasets were utilised in the study: (1) the NASA bio-Optical Marine Algorithm Dataset (NOMAD Version 2.0w APLHA, 18/07/2008 [52,53]); and (2) a dataset compiled from various locations by Shubha Sathyendranath and Trevor Platt at the Bedford Institute of Oceanography $[10,32]$. Both datasets contained matching measurements of $a_{p h}(\lambda)$ and total chlorophyll concentration $(C)$, the latter derived either from High Performance Liquid Chromatography or using a calibrated Turner fluorometer following extraction of chlorophyll in solvent. For the NOMAD dataset, $a_{p h}(\lambda)$ was derived by subtracting detrital absorption $\left(a_{d}(\lambda)\right)$ from particulate absorption $\left(a_{p}(\lambda)\right)$ measurements. Because the two datasets provided measurements of $a_{p h}(\lambda)$ at slightly different wavebands, 12 common wavebands $(412,443,490,510,520,550,560,620,665,670$, and $682 \mathrm{~nm})$ were selected for which the two datasets had wavelengths within $1 \mathrm{~nm}$ of this common set. The wavebands are also aligned with those of common multispectral ocean colour sensors. Only data within the selected study area were used (see Figure 1) and within the top $20 \mathrm{~m}$ of the water column (within the surface mixed-layer depth (rarely $<20 \mathrm{~m}$ in the open ocean [54]) or within the 1st optical depth as in the case of the NASA NOMAD dataset. For each measurement, SST data were extracted by matching each in situ sample in time (daily temporal match-up) and space (closest latitude and longitude) with daily, $1 / 4^{\circ}$ resolution Optimal Interpolation Sea Surface Temperature (OISST) data (Version 2.0 [55]) acquired from the 
National Oceanic and Atmospheric Administration (NOAA) website (http:/ / www.esrl.noaa.gov/ $\mathrm{psd} /$ data/gridded/data.noaa.oisst.v2.highres.html). In total, 1687 measurements of $a_{p h}(\lambda), C$ and SST (median $=11.5^{\circ} \mathrm{C}, \min =0.0^{\circ} \mathrm{C}, \max =30.8^{\circ} \mathrm{C}, 13.6$ percentile $=3.4^{\circ} \mathrm{C}$, and 86.4 percentile $=25.1^{\circ} \mathrm{C}$ ) were available for use, covering all months of the year.

The data were matched to daily, level 3 ( $4 \mathrm{~km}$ sinusoidal projected) satellite chlorophyll data, from version 3.1 of the Ocean Colour Climate Change Initiative (OC-CCI, a merged MERIS, MODIS-Aqua and SeaWiFS product available at http:/ / www.oceancolour.org/), between 1997-2006. Each in situ sample was matched with a single satellite pixel in time (same day) and space (closest pixel with a distance $<4 \mathrm{~km}$ away). For the 1687 samples, there were 484 corresponding satellite chlorophyll match-ups. These 484 measurements were set aside and used for independent model validation, leaving 1203 measurements for model training (parameterisation). Figure 1 shows the geographic distribution of the training and validation data.

\subsection{Four-Population Model of Phytoplankton Absorption}

Brewin et al. [46] consider the total chlorophyll-a concentration $(C)$ as the sum of chlorophyll-a concentrations in picophytoplankton $\left(C_{1}\right)$, nanophytoplankton $\left(C_{2}\right)$, dinoflagellates $\left(C_{3}\right)$ and diatoms $\left(C_{4}\right)$, such that

$$
C=\sum_{i=1}^{4} C_{i}
$$

The model first utilises two exponential functions [10], where the chlorophyll concentration of picophytoplankton $\left(C_{1}\right.$, cells $\left.<2 \mu \mathrm{m}\right)$ and combined pico- and nanophytoplankton $\left(C_{1,2}\right.$, cells $\left.<20 \mu \mathrm{m}\right)$ are obtained from

and

$$
C_{1,2}=C_{1,2}^{m}\left[1-\exp \left(-\frac{D_{1,2}}{C_{1,2}^{m}} C\right)\right]
$$

$$
C_{1}=C_{1}^{m}\left[1-\exp \left(-\frac{D_{1}}{C_{1}^{m}} C\right)\right]
$$

The parameters $D_{1,2}$ and $D_{1}$ determine the fraction of total chlorophyll in the two size classes ( $<20 \mu \mathrm{m}$ and $<2 \mu \mathrm{m}$, respectively) as total chlorophyll tends to zero, and $C_{1,2}^{m}$ and $C_{1}^{m}$ are the asymptotic maximum values for the two size classes $(<20 \mu \mathrm{m}$ and $<2 \mu \mathrm{m}$, respectively). The chlorophyll concentration of nanophytoplankton $\left(C_{2}\right)$ and microphytoplankton (combined dinoflagellates and diatoms, $\left.C_{3,4}\right)$ are calculated simply as $C_{2}=C_{1,2}-C_{1}$ and $C_{3,4}=C-C_{1,2}$. Brewin et al. [46] modelled the parameters of Equations (3) and (4) as a function of SST using the following logistic equations,

$$
C_{1,2}^{m}=1-\left\{\frac{G_{a}}{1+\exp \left[-G_{b}\left(\mathrm{SST}-G_{c}\right)\right]}+G_{d}\right\}
$$

and

$$
C_{1}^{m}=1-\left\{\frac{H_{a}}{1+\exp \left[-H_{b}\left(\mathrm{SST}-H_{c}\right)\right]}+H_{d}\right\}
$$

where $G_{a}$ and $G_{d}$ control the upper and lower bounds of $C_{1,2}^{m}, G_{b}$ represents the slope of change in $C_{1,2}^{m}$ with SST, and $G_{c}$ is the SST mid-point of the slope between $C_{1,2}^{m}$ and SST. For $C_{1}^{m}, H_{i}$, where $i=a$ to $d$, is analogous to $G_{i}$ for $C_{1,2}^{m}$. The parameters $D_{1,2}$ and $D_{1}$ were expressed as

$$
D_{1,2}=\frac{J_{a}}{1+\exp \left[-J_{b}\left(\mathrm{SST}-J_{c}\right)\right]}+J_{d}
$$

and

$$
D_{1}=\frac{K_{a}}{1+\exp \left[-K_{b}\left(\mathrm{SST}-K_{c}\right)\right]}+K_{d}
$$

where $J_{a}$ and $J_{d}$ control the upper and lower bounds of $D_{1,2}, J_{b}$ represents the slope of change in $D_{1,2}$ with SST, and $J_{c}$ is the SST mid-point of the slope between $D_{1,2}$ and SST. For $D_{1}, K_{i}$ is analogous to $J_{i}$ for $D_{1,2}$. Model parameters $G_{i}, H_{i}, J_{i}$ and $K_{i}$ are provided in Table 1. Finally, microphytoplankton $\left(C_{3,4}\right)$ is partitioned into dinoflagellates $\left(C_{3}\right)$ and diatoms $\left(C_{4}\right)$ according to, 


$$
\frac{C_{3}}{C_{3,4}}=\frac{1}{1+\exp [-\alpha(\mathrm{SST}-\beta)]},
$$

where $\alpha=0.10(0.08 \leftrightarrow 0.13)$ and $\beta=32.5$ (29.7 $\leftrightarrow 36.1)$. Using Equations (3)-(9), the chlorophyll concentrations for the four groups $\left(C_{1}, C_{2}, C_{3}\right.$ and $\left.C_{4}\right)$ can be derived from total chlorophyll (C) and SST.

Here, we expand on this approach by modelling $a_{p h}(\lambda)$ as the contribution of the four different populations of phytoplankton, picophytoplankton $\left(a_{p h, 1}(\lambda)\right)$, nanophytoplankton $\left(a_{p h, 2}(\lambda)\right)$, dinoflagellates $\left(a_{p h, 3}(\lambda)\right)$, and diatoms $\left(a_{p h, 4}(\lambda)\right)$, according to

$$
a_{p h}(\lambda)=\sum_{i=1}^{4} a_{i}^{*}(\lambda) C_{i}
$$

where $a_{i}^{*}$ are the chlorophyll-specific absorption coefficients for each population $i$. To retrieve $a_{i}^{*}$, we used the training (parameterisation) data. By integrating Equation (3)-(9) into Equations (10), and using $a_{p h}, C$ and SST as inputs, we fitted Equation (10) individually to each wavelength using a non-linear least-squared fitting procedure (Levenberg-Marquardt [56,57], IDL Routine MPFITFUN). We used the method of bootstrapping [58,59] to compute a parameter distribution (1000 bootstraps), and from the resulting parameter distribution median values and robust standard deviations in $a_{i}^{*}$ were obtained, which are provided in Table 2 for each of the 12 wavelengths in the dataset.

Table 1. Parameter values for Equation (5)-(8). Taken from Table 4 of Brewin et al. [46].

\begin{tabular}{ccccc}
\hline \multirow{2}{*}{ Model Parameter } & \multicolumn{4}{c}{ Parameters Values $^{\$}$} \\
\cline { 2 - 5 } & $\boldsymbol{i}=\boldsymbol{a}$ & $\boldsymbol{i}=\boldsymbol{b}$ & $\boldsymbol{i}=\boldsymbol{c}$ & $\boldsymbol{i}=\boldsymbol{d}$ \\
\hline \multirow{2}{*}{$G_{i}$ (Equation (5)) } & -1.51 & -1.25 & 14.95 & 0.25 \\
& $(-1.57 \leftrightarrow-1.43)$ & $(-1.41 \leftrightarrow-1.25)$ & $(14.87 \leftrightarrow 15.05)$ & $(0.23 \leftrightarrow 0.26)$ \\
\hline \multirow{2}{*}{$H_{i}$ (Equation (6)) } & 0.29 & 3.05 & 16.24 & 0.56 \\
& $(0.28 \leftrightarrow 0.30)$ & $(2.87 \leftrightarrow 3.26)$ & $(16.19 \leftrightarrow 16.29)$ & $(0.55 \leftrightarrow 0.57)$ \\
\hline \multirow{2}{*}{$J_{i}$ (Equation (7)) } & 0.370 & 1.13 & 14.89 & 0.569 \\
& $(0.367 \leftrightarrow 0.373)$ & $(1.10 \leftrightarrow 1.16)$ & $(14.87 \leftrightarrow 14.91)$ & $(0.566 \leftrightarrow 0.571)$ \\
\hline \multirow{2}{*}{$K_{i}$ (Equation (8)) } & 0.503 & 1.33 & 17.31 & 0.258 \\
& $(0.501 \leftrightarrow 0.505)$ & $(1.31 \leftrightarrow 1.37)$ & $17.28 \leftrightarrow 17.32)$ & $(0.256 \leftrightarrow 0.259)$ \\
\hline
\end{tabular}

$\$$ Bracket values refer to the $2.5 \%$ and $97.5 \%$ confidence intervals.

Table 2. Chlorophyll-specific absorption coefficients $\left(\mathrm{m}^{2}[\mathrm{mg} \mathrm{C}]^{-1}\right)$ retrieved from fitting the four-population model (Equation (10)) to the parameterisation data.

\begin{tabular}{ccccc}
\hline $\begin{array}{c}\text { Wavelength } \\
\boldsymbol{\lambda}(\mathbf{n m})\end{array}$ & $\begin{array}{c}\text { Picophytoplankton } \\
\boldsymbol{a}_{\mathbf{1}}^{*}\end{array}$ & $\begin{array}{c}\text { Nanophytoplankton } \\
\boldsymbol{a}_{\mathbf{2}}^{*}\end{array}$ & $\begin{array}{c}\text { Dinoflagellates } \\
\boldsymbol{a}_{\mathbf{3}}^{*}\end{array}$ & $\begin{array}{c}\text { Diatoms } \\
\boldsymbol{a}_{\mathbf{4}}^{*}\end{array}$ \\
\hline 412 & $0.124( \pm 0.054)$ & $0.052( \pm 0.031)$ & $0.039( \pm 0.014)$ & $0.011( \pm 0.004)$ \\
443 & $0.183( \pm 0.043)$ & $0.039( \pm 0.027)$ & $0.041( \pm 0.016)$ & $0.016( \pm 0.005)$ \\
490 & $0.118( \pm 0.025)$ & $0.022( \pm 0.018)$ & $0.035( \pm 0.008)$ & $0.009( \pm 0.003)$ \\
510 & $0.067( \pm 0.020)$ & $0.018( \pm 0.015)$ & $0.026( \pm 0.005)$ & $0.008( \pm 0.003)$ \\
520 & $0.053( \pm 0.016)$ & $0.016( \pm 0.013)$ & $0.022( \pm 0.004)$ & $0.007( \pm 0.002)$ \\
550 & $0.028( \pm 0.010)$ & $0.011( \pm 0.008)$ & $0.013( \pm 0.002)$ & $0.004( \pm 0.001)$ \\
555 & $0.023( \pm 0.009)$ & $0.011( \pm 0.007)$ & $0.012( \pm 0.002)$ & $0.003( \pm 0.001)$ \\
560 & $0.018( \pm 0.008)$ & $0.011( \pm 0.006)$ & $0.010( \pm 0.002)$ & $0.003( \pm 0.001)$ \\
620 & $0.016( \pm 0.007)$ & $0.007( \pm 0.005)$ & $0.008( \pm 0.001)$ & $0.004( \pm 0.001)$ \\
665 & $0.037( \pm 0.010)$ & $0.009( \pm 0.008)$ & $0.010( \pm 0.006)$ & $0.013( \pm 0.002)$ \\
670 & $0.052( \pm 0.013)$ & $0.011( \pm 0.010)$ & $0.011( \pm 0.008)$ & $0.015( \pm 0.002)$ \\
682 & $0.054 \pm 0.013)$ & $0.012( \pm 0.009)$ & $0.009( \pm 0.008)$ & $0.012( \pm 0.002)$ \\
\hline
\end{tabular}

Bracketed values refer to robust standard deviations. 


\subsection{Other Models That Relate Phytoplankton Absorption to Total Chlorophyll}

Using the independent validation data, the performance of the absorption model developed in the previous section at retrieving total $a_{p h}(\lambda)$ was compared with two existing phytoplankton absorption models that derive total $a_{p h}(\lambda)$ as a function of $C$ : a power-law model [23]; and a three-population model [31]. The power-law model can be expressed as

$$
a_{p h}(\lambda)=A(\lambda) C^{(1-B(\lambda))}
$$

where $A(\lambda)$ and $B(\lambda)$ are positive, wavelength-dependent parameters. These were taken from Table 2 of Bricaud et al. [23]. The three-population model can be expressed as

$$
\begin{aligned}
a_{p h}(\lambda)= & a_{1}^{*}(\lambda) C_{1}^{m}\left[1-\exp \left(-\frac{D_{1}}{C_{1}^{m}} C\right)\right]+ \\
& a_{2}^{*}(\lambda)\left\{C_{1,2}^{m}\left[1-\exp \left(-\frac{D_{1,2}}{C_{1,2}^{m}} C\right)\right]-C_{1}^{m}\left[1-\exp \left(-\frac{D_{1}}{C_{1}^{m}} C\right)\right]\right\}+ \\
& a_{3,4}^{*}(\lambda)\left\{C-C_{1,2}^{m}\left[1-\exp \left(-\frac{D_{1,2}}{C_{1,2}^{m}} C\right)\right]\right\} .
\end{aligned}
$$

In this approach, dinoflagellates $(i=3)$ and diatoms $(i=4)$ are grouped together as microphytoplankton $(i=3,4)$ and the parameters $D_{1,2}, D_{1}, C_{1,2}^{m}$ and $C_{1}^{m}$ are fixed and consequently do not vary with SST, in contrast to Equations (5)-(8). Model parameters for Equation (12) were taken from Tables 1 and 2 of Brewin et al. [31] (note in their Table $1 D_{i}=C_{i}^{m} S_{i}$ ). The performances of the three models (four-population, three-population and power-law) at estimating $a_{p h}(\lambda)$ from $C$ were evaluated using both in situ and satellite estimates of $C$.

\subsection{Statistical Tests}

Model performance was quantified using the Pearson linear correlation coefficient $(r)$ and the root mean square error $(\Psi)$ between the estimated and measured absorption coefficients. The $\Psi$ were computed according to

$$
\Psi=\left[\frac{1}{N} \sum_{i=1}^{N}\left(X_{i}^{E}-X_{i}^{M}\right)^{2}\right]^{1 / 2},
$$

where $X$ is the variable $\left(a_{p h}(\lambda)\right)$ and $N$ is the number of samples. The superscript $E$ denotes the estimated variable (e.g., from model) and $M$ the measured variable (e.g., in situ). All statistical tests were performed in $\log _{10}$ space, considering that $a_{p h}(\lambda)$ is approximately log-normally distributed [60].

\subsection{Estimation of Uncertainty in Group-Specific $a_{p h}(\lambda)$}

Because $a_{p h, i}(\lambda)$ can be expressed as the product of $a_{i}^{*}(\lambda)$ and $C_{i}$, the relative uncertainty (or relative standard deviation) in $a_{p h, i}(\lambda)$, denoted as $f_{a, i}(\lambda)$, can be approximated, based on a Taylor expansion, as

$$
f_{a, i}(\lambda)=\sqrt{f_{a, i}^{*}(\lambda)^{2}+f_{C, i}{ }^{2}}
$$

where $f_{a, i}^{*}(\lambda)$ and $f_{C, i}$ are the relative uncertainties in $a_{i}^{*}(\lambda)$ and $C_{i}$, respectively, and $i$ is the phytoplankton group. The quantity $f_{a, i}^{*}(\lambda)$ can be estimated as the standard deviation in $a_{i}^{*}(\lambda)$ divided by $a_{i}^{*}(\lambda)$ (Table 2). So with knowledge of $f_{C, i}$ we can compute $f_{a, i}(\lambda)$ through application of Equation (14).

Here, we illustrate the application of Equation (14) using a satellite image of total chlorophyll (C) and SST in the North East Atlantic (8-day chlorophyll (OC-CCI) and SST (NOAA OISST) composite between 17 and 24 June 2008). For each group (picophytoplankton, nanophytoplankton, diatoms, and dinoflagellates), $C_{i}$ and associated $\log _{10}$-transformed per-pixel uncertainties were estimated using the model of Brewin et al. [46]. Briefly, Brewin et al. [46] used an in situ and satellite match-up dataset to compute the $\log _{10}$-transformed $\Psi$ and the bias between in situ and satellite estimates of $C_{i}$, for 
14 different optical water types (OWT, see Table 5 of [46]). These values are weighted using satellite estimates of OWT membership [61] to map $\Psi$ and bias in $C_{i}$ for each pixel.

Here, we used the approach of Ciavatta et al. [62] (see their Appendix A) to transform data uncertainties between $\log$ and linear space. The $C_{i}$ data were bias-corrected and per-pixel standard deviations were computed in linear-space. We then computed $f_{C, i}$ by dividing the standard deviations by the concentrations. Finally, $f_{a, i}(\lambda)$ was computed on a per-pixel basis through application of Equation (14) using per-pixel $f_{C, i}$ and estimates of $f_{a, i}^{*}(\lambda)$ from Table 2 as input.

\section{Results and Discussion}

\subsection{Model Tuning}

To evaluate the tuning of the four-population model, estimates of $a_{p h}(\lambda)$ from the model, using $C$ and SST as input, are plotted against observations of $a_{p h}(\lambda)$ in the parameterisation data (Figure 2). The model is seen to fit well to the observations, with correlation coefficients $\geq 0.89$, comparable with the results of studies fitting other models to $a_{p h}(\lambda)$ and $C$ data [31,32], and root mean square errors ( $\Psi$ ) ranging between 0.20 and 0.27 for all wavelengths (Figure 2).
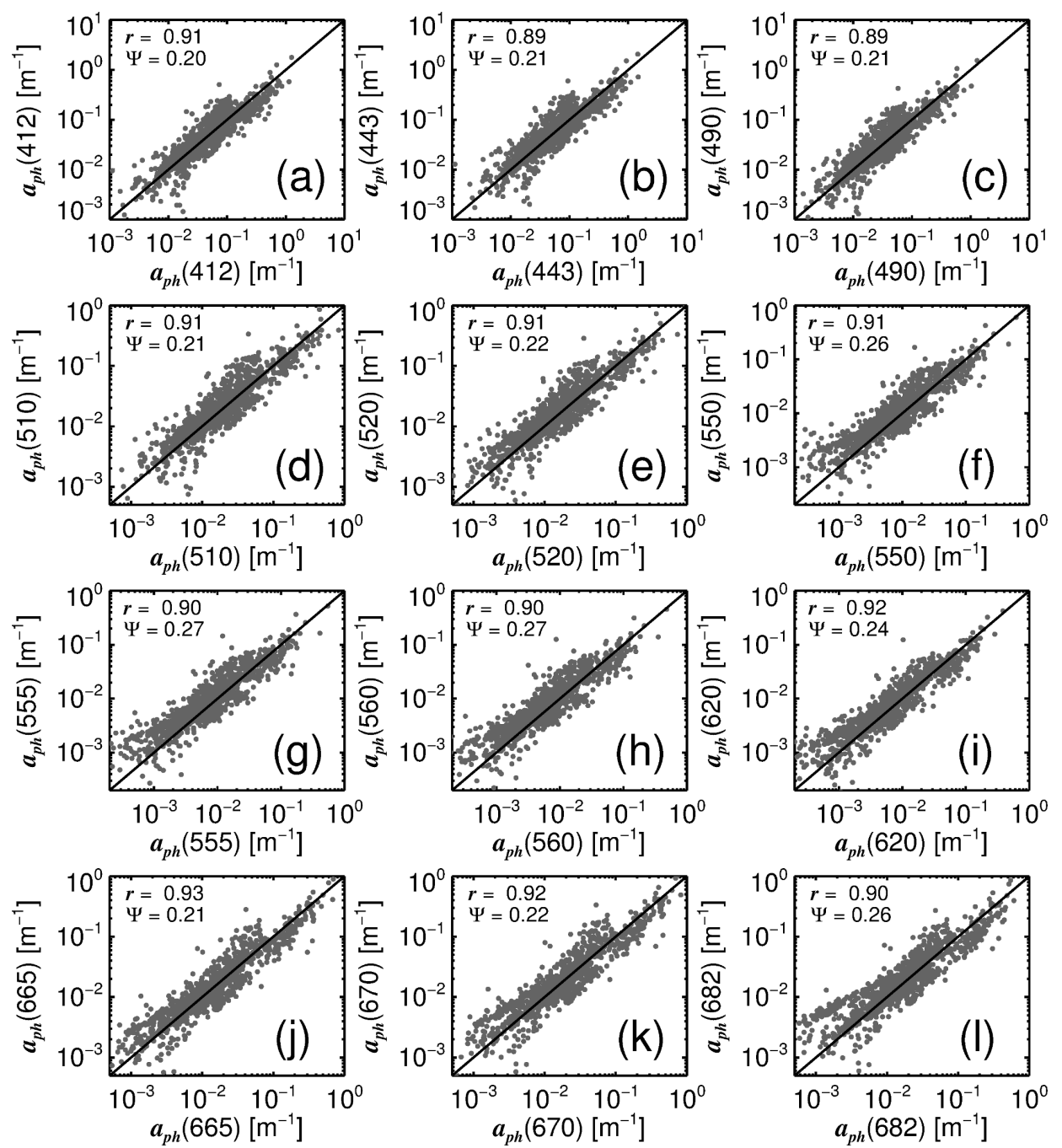

Figure 2. Comparison of modelled $a_{p h}(\lambda)$ using total chlorophyll $(C)$ and sea surface temperature (SST) as input and measured $a_{p h}(\lambda)$ from the training data. (a-1) show $a_{p h}(\lambda)$ scatter plots at each of the 12 wavelengths in the data. Modelled data is on the ordinate and measurements on the abscissa. 
The retrieved $a_{i}^{*}(\lambda)$ values for each phytoplankton group, computed from fitting Equation (10) to the parameterisation data, are shown in Figure $3 a$ and their spectral forms $\left(a^{*}(\lambda)\right.$ normalised at $510 \mathrm{~nm}$ ) in Figure 3b. Picophytoplankton have the highest $a^{*}(\lambda)$ and the steepest spectral form. Diatoms display the lowest $a^{*}(\lambda)$ values and the flattest spectral form. Nanophytoplankton and dinoflagellates $a^{*}(\lambda)$ lie between picophytoplankton and diatoms. The $a^{*}(\lambda)$ of all groups have peaks around $443 \mathrm{~nm}$ and $670 \mathrm{~nm}$ associated with chlorophyll-a absorption. Changes in $a^{*}(\lambda)$ magnitude and spectral form (shape) from picophytoplankton (smallest cells) to diatoms (large cells) are consistent with changes in size associated with packaging and pigment composition [17-22,63,64].
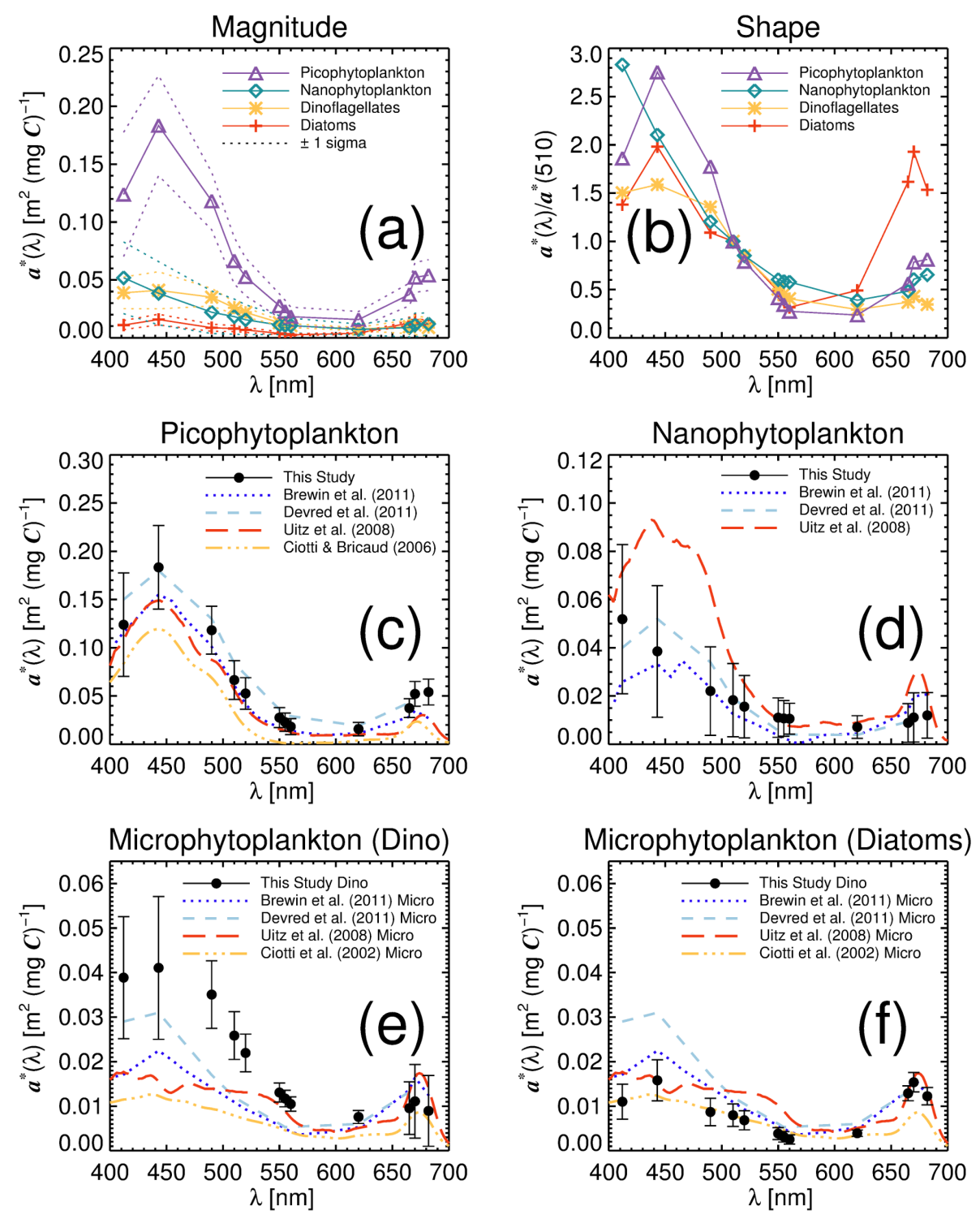

Figure 3. Phytoplankton group chlorophyll-specific absorption coefficients $\left(a_{i}^{*}(\lambda)\right)$ derived from tuning the four-population model. (a) Magnitude of $a_{i}^{*}(\lambda)$ for each group and (b) spectral form (shape) computed by normalisation of $a_{i}^{*}(\lambda)$ at $510 \mathrm{~nm}$. Comparison of retrieved $a^{*}(\lambda)$ values of: (c) picophytoplankton with other studies $[14,31,33,65]$; (d) nanophytoplankton with other studies [14,31,33]; (e) dinoflagellates with other studies of microphytoplankton [12,14,31,33]; and (f) diatoms with other studies of microphytoplankton $[12,14,31,33]$. Note the different scales of the ordinate axis. 
Retrieved picophytoplankton $a^{*}(\lambda)$ compare well with results from other studies (Figure 3c). Retrieved values are higher than those of Ciotti and Bricaud [65], but in good agreement with Brewin et al. [31], Devred et al. [14], and Uitz et al. [33], with confidence intervals overlapping for most wavelengths. Agreement with the Brewin et al. [31] and Devred et al. [14] studies is not surprising, considering data used here are not entirely independent of the data used in these two earlier studies. Values are slightly closer to Devred et al. [14] at 443, 490, and $670 \mathrm{~nm}$, and Brewin et al. [31] and Uitz et al. [33] at other wavelengths. High picophytoplankton $a^{*}(\lambda)$ values at blue wavelengths have been attributed to the presence of non-photosynthetic cartenoids, such as zeaxanthin or $\beta$-carotene, that absorb in this region of the spectrum [66]. Picophytoplankton $a^{*}(443)$ values obtained here $\left(0.183 \mathrm{~m}^{2}[\mathrm{mg} \mathrm{C}]^{-1}\right)$ are similar to those from monospecific laboratory cultures of Prochlorococcus [67-69].

Retrieved $a^{*}(\lambda)$ values for nanophytoplankton (Figure 3d) also agree with those of Brewin et al. [31] and Devred et al. [14], but are slightly lower than Uitz et al. [33] in the blue and red region of the spectrum. Large error bars in retrieved $a^{*}(\lambda)$ for nanophytoplankton indicate a high natural variability in $a^{*}(\lambda)$ for this group. It is not surprising considering that nanophytoplankton span a relatively large size range and are known to have high levels of diversity [70]. The high value at $412 \mathrm{~nm}$ obtained in this study, relative to other wavelengths, is somewhat surprising when compared with earlier studies. However, large error bars suggest differences are not significant with other wavelengths in the blue region of the spectrum.

Retrieved $a^{*}(\lambda)$ values for dinoflagellates and diatoms are plotted against results of other studies on microphytoplankton in Figure 3e,f. It is worth considering that, though both dinoflagellates and diatoms are typically microphytoplankton, the microphytoplankton $a^{*}(\lambda)$ from other studies are not expected to match exactly the dinoflagellates and diatoms $a^{*}(\lambda)$ from this study, since microphytoplankton $a^{*}(\lambda)$ represents a combination of both groups. In general, dinoflagellate $a^{*}(\lambda)$ is higher than the Brewin et al. [31] and Devred et al. [14] studies and diatom $a^{*}(\lambda)$ lower. Dinoflagellate $a^{*}(\lambda)$ is higher than all other studies between 490 and $510 \mathrm{~nm}$, but overlaps with Devred et al. [14] in blue regions (412 and $443 \mathrm{~nm}$ ), agrees with Uitz et al. [33] in green regions (550 to $560 \mathrm{~nm}$ ) and overlaps with all studies in the red region ( 665 to $683 \mathrm{~nm}$ ). Diatom $a^{*}(\lambda)$ is in good agreement with estimates from Ciotti et al. [12] in blue and green regions of the spectrum (412 to $620 \mathrm{~nm}$ ) but in better agreement with Brewin et al. [31], Devred et al. [14] and Uitz et al. [33] in the red (665 to $683 \mathrm{~nm}$ ). Lowest $a^{*}(\lambda)$ values for diatoms in blue and green wavelengths can be linked to the strong package effect occurring in this group [11]. Values of $a^{*}(443)$ for diatoms and dinoflagellates are also comparable with laboratory studies on these groups [71,72].

Differences in $a_{i}^{*}(\lambda)$ among studies (Figure 3) may be due to a variety of reasons. While on the one hand the datasets used in this paper have been used previously by the bio-optical community for studying phytoplankton absorption and community structure $[10,11,14,32,59,73,74]$, and are among the few datasets available for such large spatial-scale analysis, the complication of data collected by different investigators and in different laboratories will always be vulnerable to variations in lab-procedures and techniques [52]. Increasing efforts are being made by the international community to minimise such differences, by improving international protocols for measuring properties like $a_{p h}$ (e.g., [75]). Differences in $a_{i}^{*}(\lambda)$ among studies (Figure 3) may also be dependent on the methods used to derive phytoplankton composition $\left(C_{i}\right)$. The model of Brewin et al. [46] was fitted using a combination of High Performance Liquid Chromatography (HPLC) pigment data and sequential size-fractionated chlorophyll measurements. This is different to other studies, for example, Uitz et al. [33] used HPLC data only, and the use of HPLC in their study for deriving phytoplankton composition was not exactly the same as that used in the Brewin et al. [46] study, which introduced modifications to the method [14,34]. The Ciotti et al. [12] study used a combination of methods allocating spectra based on dominant group, and Devred et al. [14] used $a_{p h}$ and $C$ to derive $C_{i}$, making assumptions about the composition at extreme (low) ends. Differences in $a_{i}^{*}(\lambda)$ among studies (Figure 3) may also be related to regional and seasonal differences in the datasets used, and differences in mathematical and 
statistical methods for determining $a_{i}^{*}(\lambda)$ (e.g., fitting procedures, variations in the use of parametric and non-parametric statistics).

\subsection{Model Validation}

The validation data were used to verify the performance of the four-population model at retrieving total $a_{p h}(\lambda)$. The model was tested using both in situ and satellite total chlorophyll-a (C) as input. For the in situ validation, correlation coefficients $(r)$ ranged from 0.87 to 0.92 and root mean square errors ( $\Psi$ ) between 0.21 and 0.29 (Table 3 ), in good agreement with statistical tests performed on the parameterisation data (Figure 2). For the satellite validation, lower $r$ values $(0.76$ to 0.80$)$ and higher $\Psi$ ( 0.27 to 0.39 ) were obtained (Table 3 ). However, results from these statistical tests are influenced by discrepancies between in situ and satellite chlorophyll-a (see footnote to Table 3), and are comparable with other validation studies estimating $a_{p h}(\lambda)$ from remote sensing reflectance $\left(R_{r s}\right)$ data [76].

The performance of the four-population model at retrieving $a_{p h}(\lambda)$ was found to be comparable with results of two other models that estimate $a_{p h}(\lambda)$ as a function of total chlorophyll-a (C) [23,31], using both in situ and satellite total chlorophyll-a $(C)$ as inputs (Table 3$)$. There were no significant differences in $r$ among models according to the $z$-score ( $p>0.05$, see [76] for computation of $z$-score). There were also no significant differences in $\Psi$, with $95 \%$ confidence intervals in $\Psi$ overlapping (computed from the standard error and the t-distribution of the sample size), with the exception of $412 \mathrm{~nm}$. Here, the four-population model had significantly lower $\Psi$ than both the three-population model and the power-law model in both validation cases (using in situ and satellite $C$ as input). Furthermore, at $443 \mathrm{~nm}$, and in both validation cases, the four-population and three-population model had significantly lower $\Psi$ than the power-law model.

With respect to estimating total $a_{p h}(\lambda)$ only from total chlorophyll-a $(C)$, and considering performance similar to the two simpler models at most wavelengths (that have fewer parameters), the four-population model is a less parsimonious model. However, the four-population model has advantages over the two simpler models, including: (1) its parameters have clear interpretations and the approach ensures plausible values of $a^{*}(\lambda)$ at extreme chlorophyll-a concentrations, unlike an empirical power function; (2) the model can determine $a_{p h}(\lambda)$ for four phytoplankton groups, rather than three as in the three-population model; and (3) the model incorporates the effect of changes in SST on total and group-specific $a_{p h}(\lambda)$, which could be important when modelling phytoplankton absorption in a future, warmer ocean under climate change. 
Table 3. Comparison of the performance of the four-population model at retrieving $a_{p h}(\lambda)$ with the model of Brewin et al. [31] and Bricaud et al. [23] using the validation data, and both in situ and satellite chlorophyll-a data as input.

\begin{tabular}{|c|c|c|c|c|c|c|c|c|c|c|c|c|}
\hline \multirow{3}{*}{ Wavelength (nm) } & \multicolumn{6}{|c|}{ In Situ Chlorophyll-a as Input * } & \multicolumn{6}{|c|}{ Satellite Chlorophyll-a as Input * } \\
\hline & \multicolumn{2}{|c|}{ This Study } & \multicolumn{2}{|c|}{ Brewin et al. [31] } & \multicolumn{2}{|c|}{ Bricaud et al. [23] } & \multicolumn{2}{|c|}{ This Study } & \multicolumn{2}{|c|}{ Brewin et al. [31] } & \multicolumn{2}{|c|}{ Bricaud et al. [23] } \\
\hline & $r$ & $\Psi$ & $r$ & $\Psi$ & $r$ & $\Psi$ & $r$ & $\Psi$ & $r$ & $\Psi$ & $r$ & $\Psi$ \\
\hline 412 & 0.89 & 0.21 & 0.88 & 0.23 & 0.89 & 0.26 & 0.80 & 0.28 & 0.80 & 0.31 & 0.80 & 0.34 \\
\hline 443 & 0.87 & 0.22 & 0.86 & 0.22 & 0.87 & 0.25 & 0.78 & 0.27 & 0.78 & 0.29 & 0.78 & 0.32 \\
\hline 490 & 0.87 & 0.21 & 0.86 & 0.21 & 0.86 & 0.22 & 0.77 & 0.27 & 0.78 & 0.27 & 0.78 & 0.29 \\
\hline 510 & 0.89 & 0.21 & 0.89 & 0.21 & 0.89 & 0.22 & 0.79 & 0.28 & 0.80 & 0.29 & 0.80 & 0.30 \\
\hline 520 & 0.90 & 0.21 & 0.90 & 0.21 & 0.91 & 0.22 & 0.80 & 0.29 & 0.81 & 0.30 & 0.81 & 0.31 \\
\hline 550 & 0.90 & 0.26 & 0.90 & 0.25 & 0.91 & 0.24 & 0.80 & 0.34 & 0.80 & 0.36 & 0.81 & 0.33 \\
\hline 555 & 0.90 & 0.26 & 0.89 & 0.26 & 0.91 & 0.24 & 0.80 & 0.35 & 0.80 & 0.37 & 0.81 & 0.34 \\
\hline 560 & 0.90 & 0.27 & 0.89 & 0.27 & 0.91 & 0.24 & 0.80 & 0.35 & 0.80 & 0.38 & 0.82 & 0.33 \\
\hline 620 & 0.91 & 0.25 & 0.91 & 0.23 & 0.91 & 0.23 & 0.79 & 0.36 & 0.80 & 0.35 & 0.81 & 0.34 \\
\hline 665 & 0.92 & 0.22 & 0.92 & 0.22 & 0.92 & 0.21 & 0.80 & 0.34 & 0.81 & 0.33 & 0.81 & 0.34 \\
\hline 670 & 0.91 & 0.23 & 0.92 & 0.22 & 0.92 & 0.22 & 0.79 & 0.34 & 0.80 & 0.33 & 0.80 & 0.34 \\
\hline 682 & 0.88 & 0.29 & 0.89 & 0.26 & 0.89 & 0.26 & 0.76 & 0.39 & 0.78 & 0.37 & 0.78 & 0.37 \\
\hline
\end{tabular}

* All statistical tests are performed on $\log _{10}$-transformed $a_{p h}(\lambda)$ data. A statistical comparison between $\log _{10}$-transformed in situ and satellite chlorophyll-a yielded $r=0.80$ and $\Psi=0.34$ 


\subsection{Variations in $a_{p h}(\lambda)$ with Temperature and Community Structure}

The four-population model allows us to explore the impact of changes in SST on phytoplankton community structure and consequently $a_{p h}(\lambda)$. Figure $4 \mathrm{a}$, b shows the effect of SST on total $a_{p h}(443)$ and total $a^{*}(443)$ as functions of total chlorophyll-a (C). Larger differences are seen at lower chlorophyll concentrations, where the $a^{*}(443)$ (and consequently $a_{p h}(443)$ ) are higher in warmer waters. This is a consequence of a change in the composition of phytoplankton (Figure $4 \mathrm{c}, \mathrm{d}$ ) from a dominance (in terms of $C$ ) of picophytoplankton in warmer, low-chlorophyll waters (Figure 4c, picophytoplankton have higher $a^{*}(443)$, see Figure 3), to nanophytoplankton in cooler, low-chlorophyll waters (Figure 4d, nanophytoplankton have lower $a^{*}(443)$, see Figure 3). The four-population model constrains $a^{*}(443)$ at very high and very low chlorophyll-a concentrations, since the range of values of $a^{*}(\lambda)$ is bounded by the values associated with the populations. However, as the populations change with SST, so do the bounds (Figure $4 \mathrm{~b}$ ). Interestingly, the functional relationship between $a^{*}(443)$ and $C$ is in good qualitative agreement with the hyperbolic tangent function of Carder et al. [28] (Figure 4b). Though biases are observed at the higher end of chlorophyll concentrations, temperate parameters of the Carder et al. [28] model (likely representative of cooler waters) are shifted lower than those from subtropical water (likely representative of warmer waters), consistent with the four-population model at lower chlorophyll concentration $\left(<1 \mathrm{mg} \mathrm{m}^{-3}\right)$.
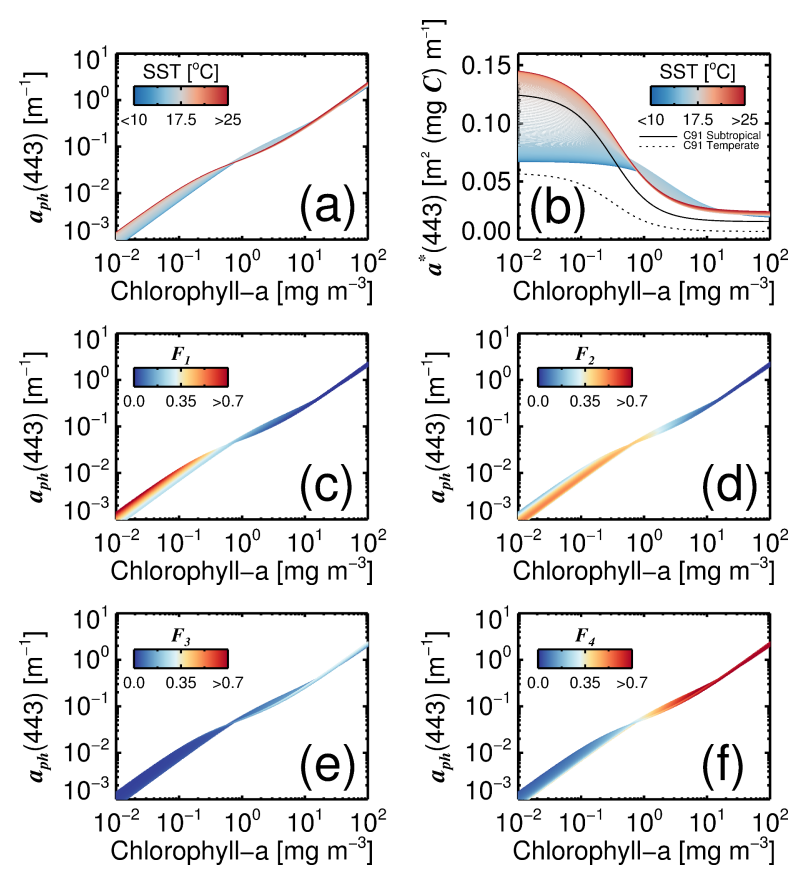

Figure 4. Estimates of $a_{p h}(443)$ as a function of total chlorophyll-a (C) using the four-population model. (a) Influence of SST on estimates of $a_{p h}(443)$ as a function of $C$. (b) Influence of SST on estimates of $a^{*}(443)$ as a function of $C$ : C91 refers to the model of Carder et al. [28], for subtropical and temperate waters. $(\mathbf{c}-\mathbf{f})$ The fractions $\left(F_{i}\right)$ of each phytoplankton group $(1=$ picophytoplankton, $2=$ nanophytoplankton, $3=$ dinoflagellates, and $4=$ diatoms) relative to $C$ for the same model simulations.

Estimates of total $a^{*}(\lambda)$ for a range of total chlorophyll-a concentrations $(C)$ are plotted in Figure 5 using the four-population model for three contrasting temperature values: $24^{\circ} \mathrm{C} ; 17^{\circ} \mathrm{C}$; and $10^{\circ} \mathrm{C}$. The change in the upper bound of $a^{*}(\lambda)$ with SST at low chlorophyll is most apparent in the blue part of the spectrum, but still occurs in the green and red (Figure $5 a-c)$. Figure $5 d-0$ show the fractional contribution to specific absorption of each of the four phytoplankton groups, relative to total $a_{p h}(\lambda)$, for the same simulations. In general, picophytoplankton control total $a^{*}(\lambda)$ at low chlorophyll concentration, nanophytoplankton at intermediate chlorophyll, and diatoms and dinoflagellates at high chlorophyll. However, there are clear spectral variations, as well as variations with temperature. 
Although nanophytoplankton dominate the fractional contribution of each group relative to total chlorophyll at low SST and low chlorophyll (Figure 4a,d), picophytoplankton are more efficient in absorbing light and consequently have a greater influence on $a_{p h}(\lambda)$ in the same temperature and chlorophyll range.
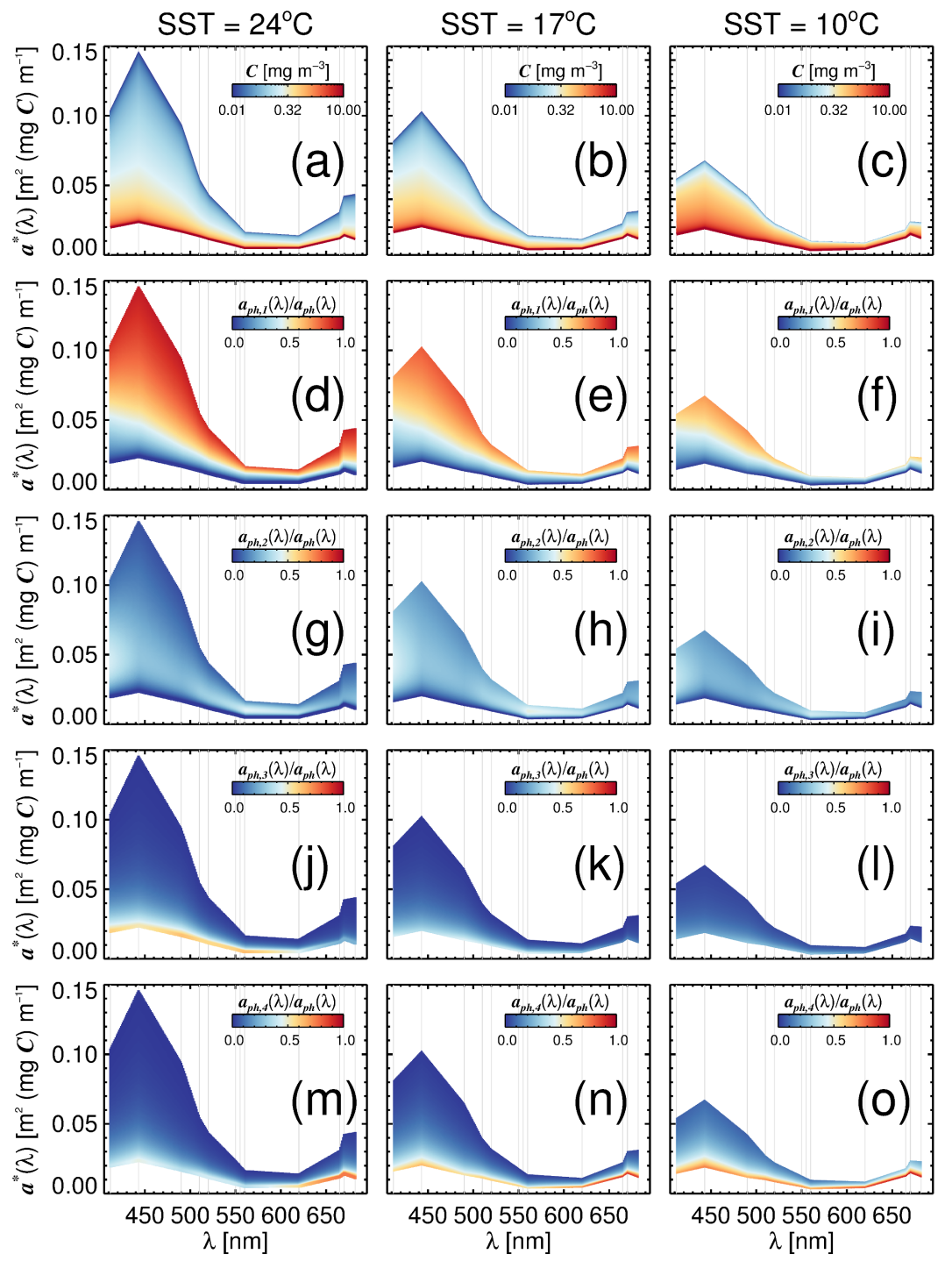

Figure 5. Estimates of $a^{*}(\lambda)$ as a function of total chlorophyll-a $(C)$ using the four-population model at three contrasting temperature ranges: $(\mathbf{a}, \mathbf{d}, \mathbf{g}, \mathbf{j}, \mathbf{m})$ at $24^{\circ} \mathrm{C} ;(\mathbf{b}, \mathbf{e}, \mathbf{h}, \mathbf{k}, \mathbf{n})$ at $17^{\circ} \mathrm{C}$; and $(\mathbf{c}, \mathbf{f}, \mathbf{i}, \mathbf{l}, \mathbf{o})$ at $10^{\circ} \mathrm{C}$. $(\mathbf{a}-\mathbf{c}) a^{*}(\lambda)$ for a given total chlorophyll-a $(C)$ at the three temperature ranges. (d-o) The fractional contribution of each group ( 1 = picophytoplankton, 2 = nanophytoplankton, $3=$ dinoflagellates and 4 = diatoms) relative to $a_{p h}(\lambda)$ for each simulation at the three temperature ranges: (d-f) picophytoplankton; $(\mathbf{g}-\mathbf{i})$ nanophytoplankton; $(\mathbf{j}-\mathbf{l})$ dinoflagellates; and $(\mathbf{m}-\mathbf{o})$ diatoms. Thin grey lines represent wavelengths in the model, all other wavelengths are estimated from linear interpolation between neighbouring wavebands and should be interpreted cautiously.

\subsection{Towards a Mechanistic Understanding of Temperature in the Four-Population Model}

SST influence in the four-population model is represented through the parameters that control the relationship between group-specific chlorophyll $\left(C_{i}\right)$ and total chlorophyll (C) (Equation (5)-(8)): the asymptotic maximum value for cells $<20 \mu \mathrm{m}$ and $<2 \mu \mathrm{m}\left(C_{1,2}^{m}\right.$ and $\left.C_{1}^{m}\right)$, the fraction of total chlorophyll in two size classes $(<20 \mu \mathrm{m}$ and $<2 \mu \mathrm{m})$ as total chlorophyll tends to zero $\left(D_{1,2}\right.$ and 
$\left.D_{1}\right)$, and the fractional contribution of dinoflagellates $\left(C_{3}\right)$ and diatoms $\left(C_{4}\right)$ to microphytoplankton chlorophyll $\left(C_{3,4}\right.$, cells $\left.>20 \mu \mathrm{m}\right)$. The extent to which temperature has a direct or an indirect influence on phytoplankton community structure is an area of active research [40,42,77-79].

In the favour of direct control, temperature is known to influence the physiology of phytoplankton [80]. As highlighted by López-Urrutia and Morán [78], temperature impacts uptake rates of nutrients, for example, through temperature-dependent metabolic processes that influence nutrient ion handling times, or through modifying nutrient diffusion and fluid viscosity [81]. Temperature also can influence resource allocation; for example, the relative nitrogen-to-phosphorus demands in phytoplankton have been linked to temperature [82]. Phytoplankton loss terms (e.g., grazing) have been related to parameters of the model (e.g., the asymptotic maximum value for small cells [83]) and to temperature. For example, López-Urrutia [84] found that temperature can modify the grazing interactions between phytoplankton and their predators. All these factors will directly influence bottom-up and top-down control on these phytoplankton groups.

Nonetheless, the relationship between temperature and model parameters may simply be an indirect effect of covariation between temperature and resource supply $[77,79]$. Inverse relationships between temperature and nutrients are well known in the region [85], as are positive relationships between temperature and light availability in the mixed-layer [46]. Temperature may also covary with the spectral quality of light in the mixed layer, which has also been shown to influence phytoplankton community structure [2]. The influence of temperature on model parameters has not only been seen in the North Atlantic study of Brewin et al. [46], but also in other studies, using different datasets and methods, and in different regions, from polar to tropical waters [86,87]. Future work is needed to understand mechanistically how temperature influences model parameters. For example, the evidence and length of lags between temperature and changes in phytoplankton community structure could be useful for understanding direct and indirect effects.

\subsection{Impact of Variations in $a_{p h}(\lambda)$ on the Blue-to-Green Ratio of Remote-Sensing Reflectance}

We integrated the four-population absorption model into a simple model of ocean colour (see Appendix A). This model was used for the sole purpose of illustrating the influence of changes in SST on phytoplankton community structure, and consequently, the blue-to-green ratio of remote-sensing reflectance. Figure 6 shows the blue-to-green maximum band ratio of remote sensing reflectance $\left(R_{r s}(443>490>510) / R_{r s}(555)\right)$ plotted as a function of total chlorophyll-a $(C)$ and SST using this model. Overlain on these simulations is the globally-tuned NASA OC4v6 model $[88,89]$.

Variations in the maximum band ratio at higher chlorophyll $\left(>1 \mathrm{mg} \mathrm{m}^{-3}\right)$ are relatively small and agree well with the empirical OC4v6 model. Larger differences emerge at lower chlorophyll $\left(<1 \mathrm{mg} \mathrm{m}^{-3}\right)$. Here, there is a significant increase in blue light relative to green light with decreasing SST (Figure 6a). This change is characterised by a shift in the composition of phytoplankton from small cells (picophytoplankton) in warmer waters to larger cells (nanophytoplankton and diatoms) in cooler waters (Figure $6 \mathrm{~b}-\mathrm{d}$ ). Interestingly, the OC4v6 algorithm tracks the warmer water simulations in these low chlorophyll waters, possibly reflecting the distribution of data in the database used to parameterise the OC4v6 algorithm; after all, low chlorophyll waters are generally more prevalent in subtropical (warmer water) regions. In fact, the median SST (OISST) for HPLC chlorophyll-a concentrations $<0.4 \mathrm{mg} \mathrm{m}^{-3}$ in the NOMAD database (Version 2.0 ALPHA, parts of which were used to parameterise $\mathrm{OC} 4 \mathrm{v} 6$ ) is $20^{\circ} \mathrm{C}$, a temperature range where model simulations and OC4v6 agree reasonably (Figure 6a).

Results for the simulations in Figure 6 are consistent with results of some regional studies in cold waters. For example, empirical algorithms that estimate total chlorophyll-a from reflectance ratios typically report higher ratios for the same chlorophyll in the Southern Ocean $[90,91]$, which has been attributed to changes in pigment packaging and a shift toward larger celled phytoplankton [86,92]. Other studies have shown that, in high latitude regions, often characterised by the presence of diatoms, blue-to-green reflectance ratios are higher than in low latitude regions, for similar 
chlorophyll and coloured dissolved organic matter (CDOM) concentrations [10]. With predicted changes in ocean temperature in the North Atlantic [93], and consequently phytoplankton population, the four-population model could be useful for exploring consequential changes in ocean colour, or verifying bio-optical ecosystem model projections of ocean colour [94].

In fact, it has been suggested [94] that parts of the future ocean could be bluer as phytoplankton concentration and community composition is modified due to climate change. The results presented here (Figures 5 and 6) raise the possibility that temperature-dependent alterations in the phytoplankton absorption properties could counteract any such tendencies to some extent: We see in Figure 6 that the blue-to-green ratio of remote-sensing reflectance decreases with increasing temperature, for a given chlorophyll concentration, and especially for low-chlorophyll waters. To resolve the question of whether such patterns would persist in a future ocean decades away from now, we need to understand better the reasons for a temperature dependence in absorption (see Section 3.4). Another possibility is that higher temperatures are associated with high-light environments, and that the temperature effect observed here is actually a consequence of photo-acclimation: in high-light environment, phytoplankton are expected to have lower chlorophyll per cell than in low-light conditions, which in turn would lead to reduced flattening effect on phytoplankton absorption and higher phytoplankton absorption in the blue relative to green. But such discussions must remain speculative at present, until further investigations can be carried out to test the cause of the observed temperature dependence of phytoplankton absorption.

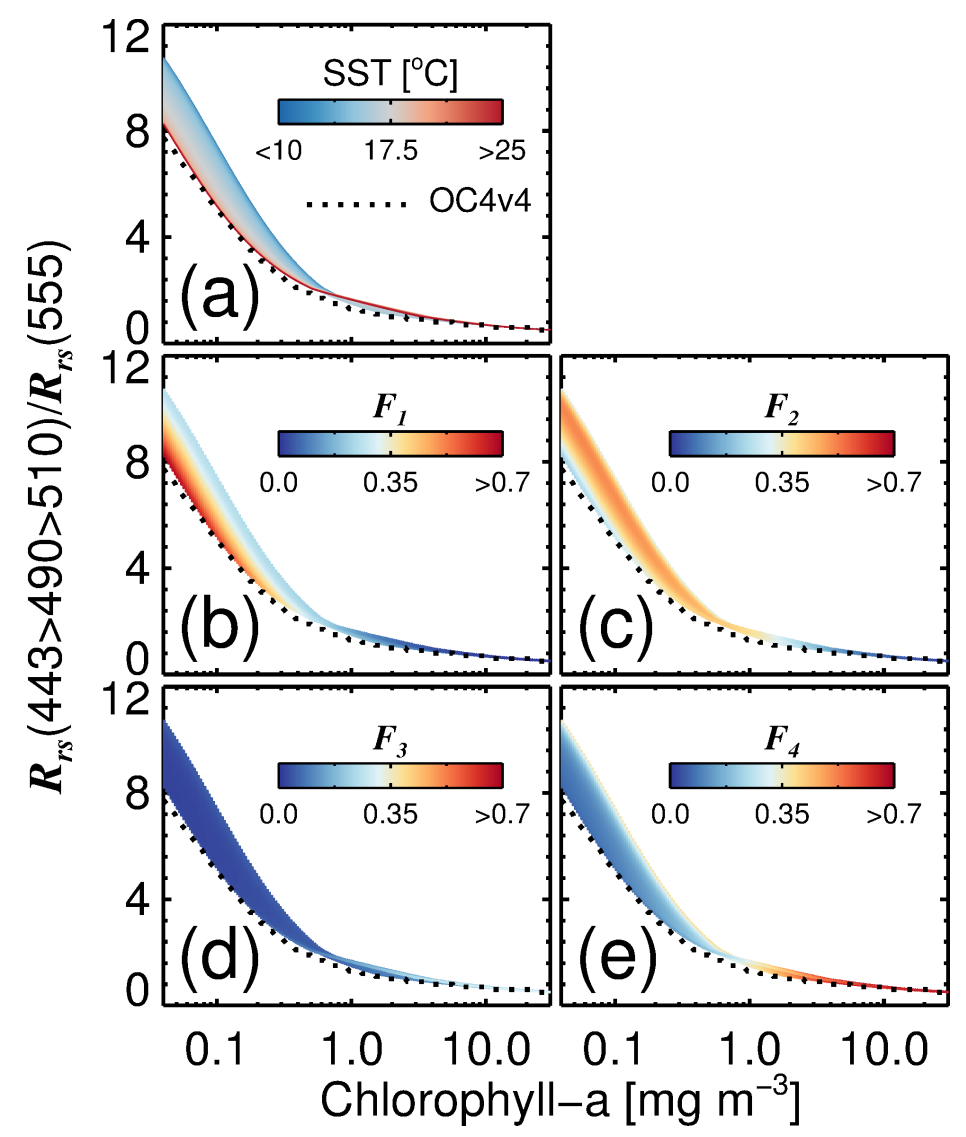

Figure 6. The blue-to-green maximum band ratio of remote sensing reflectance $\left(R_{r s}\right)$ plotted as a function of total chlorophyll-a $(C)$ and SST using a model of ocean colour that integrates the four-population absorption model (see Appendix). (a) Impact of variations in SST on estimates of the maximum band ratio. (b-e) The fractions $\left(F_{i}\right)$ of each phytoplankton group $(1=$ picophytoplankton, 2 = nanophytoplankton, 3 = dinoflagellates, and $4=$ diatoms) relative to $C$ for the same model simulations. Dashed line represents the NASA OC4v6 model $[88,89]$. 


\subsection{Mapping Uncertainty in Group-Specific $a_{p h}(\lambda)$}

Figure 7 illustrates an application of the four-population model and Equation(14) in the North East Atlantic, to estimate, from satellite data, $a_{p h}(443)$ for each group (diatoms, dinoflagellates, nanophytoplankton, and picophytoplankton, Figure $7 \mathrm{e}, \mathrm{h}, \mathrm{k}, \mathrm{n}$ ) and the uncertainty in these estimates (Figure $7 \mathrm{f}, \mathrm{i}, 1, \mathrm{o}$ ), from knowledge of the chlorophyll concentrations for each group (Figure 7d,g,j,m), derived from total chlorophyll and SST (Figure 7a,c), uncertainties in the chlorophyll concentrations for each group (from OWT data, Figure 7b, and Table 5 of [46]), and uncertainties in $a^{*}(443)$ (Table 2). Uncertainty is lowest for picophytoplankton (median 96\%), followed by dinoflagellates (median $121 \%$ ), nanophytoplankton (median 124\%), and diatoms (median $140 \%$ ). In general, for all groups, there is an increase in uncertainty with increasing total chlorophyll and OWT. This is most pronounced for dinoflagellates. Reducing uncertainty in these estimates requires reducing the uncertainties in the input to Equation (14) (group specific $a^{*}(443)$ and $C$ ), which will require improvements in the in situ measurements of phytoplankton group chlorophyll and $a_{p h}(\lambda)$, and better characterisation of uncertainties associated with differences in the observational scales between satellite and in situ data [95], since uncertainties in group-specific chlorophyll are based on satellite and in situ data match-ups [46].

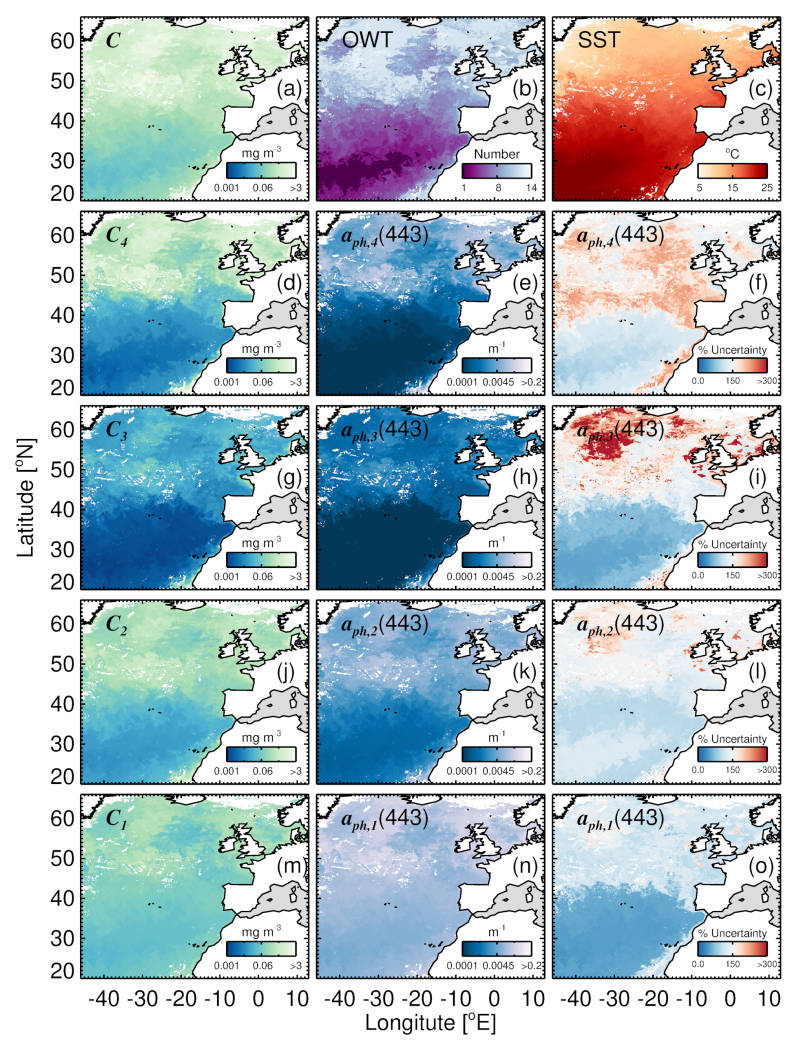

Figure 7. Satellite estimates of phytoplankton group chlorophyll, $a_{p h}(443)$ and per-pixel errors in $a_{p h}(443)$ for an eight day composite (17 to 24 June 2008) of Ocean Colour Climate Change Initiative (OC-CCI) chlorophyll and NOAA Optimal Interpolation Sea Surface Temperature (OISST) SST using the four-population absorption model and Equation (14). (a) Total chlorophyll, (b) dominant optical water type (OWT), and (c) SST data. These are used as input to the four-population absorption model to predict: (d) diatom chlorophyll $\left(C_{4}\right)$; (e) diatom absorption at $443 \mathrm{~nm}\left(a_{p h, 4}(443)\right)$; (f) \% uncertainty in $a_{p h, 4}(443)$; (g) dinoflagellate chlorophyll $\left(C_{3}\right)$; (h) dinoflagellate absorption at $443 \mathrm{~nm}\left(a_{p h, 3}(443)\right)$; (i) \% uncertainty in $a_{p h, 3}(443)$; (j) nanophytoplankton chlorophyll $\left(C_{2}\right)$; (k) nanophytoplankton absorption at $443 \mathrm{~nm}\left(a_{p h, 2}(443)\right) ;(\mathbf{l}) \%$ uncertainty in $a_{p h, 2}(443) ;(\mathbf{m})$ picophytoplankton chlorophyll $\left(C_{1}\right) ;(\mathbf{n})$ picophytoplankton absorption at $443 \mathrm{~nm}\left(a_{p h, 1}(443)\right)$; and (o) \% uncertainty in $a_{p h, 1}(443)$. 
Increasing efforts to incorporate bio-optical modules into multi-phytoplankton ecosystem models are underway (e.g., [94,96]). These modules open a path to assimilating satellite-based phytoplankton group-specific optical properties, such as phytoplankton absorption. It has recently been demonstrated that significant improvements in the forecasting and reanalysis of biogeochemical indicators by multi-phytoplankton ecosystem models can be achieved by assimilating satellite estimates of group-specific chlorophyll concentration, compared with assimilating only total chlorophyll $[47,48]$. Furthermore, there are advantages to assimilating optical data directly, rather than concentrations $[49,97,98]$. The CMEMS project "Optical data modelling and assimilation" seeks to move one step further and assimilate phytoplankton group-specific $a_{p h}(\lambda)$ into the ERSEM model that is run operationally by the CMEMS MFC of the North West European Shelf-Seas. As demonstrated in Figure 7, such satellite products are becoming available, together with per-pixel uncertainties, which are highly desirable for use in data assimilation, as well as other applications.

\section{Summary}

We use the regional phytoplankton group chlorophyll-a model of Brewin et al. [46] to extend a three-population phytoplankton absorption model [31] to a four-population model. The new model estimates the spectral phytoplankton absorption coefficient $\left(a_{p h}(\lambda)\right)$ of four phytoplankton groups (picophytoplankton, nanophytoplankton, dinoflagellates, and diatoms) as a function of the total chlorophyll-a concentration (C) and SST. A dataset of $a_{p h}(\lambda)$ (at 12 wavelengths), $C$ and SST measurements, compiled from the surface layer of the North Atlantic, was partitioned into training and validation data, the validation data being matched to satellite ocean-colour observations. The model was fitted to the training data to yield the chlorophyll-specific absorption coefficient $\left(a^{*}(\lambda)\right)$ for each of the four groups, which compared well with previous field and laboratory studies.

The model was tested using independent validation data and was found to retrieve total $a_{p h}(\lambda)$ with a similar performance to two earlier models [23,31], using either in situ or satellite total chlorophyll-a data as input. Unlike these earlier models, the new model can determine $a_{p h}(\lambda)$ for four phytoplankton groups and includes the influence of changes in SST on total and group-specific $a_{p h}(\lambda)$. We incorporated the new four-population absorption model into a model of ocean colour to demonstrate the influence of change in SST on phytoplankton community structure, and consequently on ocean colour. We also provide a technique for propagating uncertainty through the model and illustrate it using a satellite image. We expect the model to be useful for optical ecosystem model validation and assimilation exercises and for exploring the influence of temperature change on community structure and consequently ocean colour.

Author Contributions: Conceptualization, R.J.W.B., S.C., J.S., J.B. and D.F.; Methodology, R.J.W.B.; Software, R.J.W.B.; Validation, R.J.W.B.; Formal Analysis, R.J.W.B.; Investigation, R.J.W.B. and S.C.; Resources, R.J.W.B., S.S. and T.P.; Data Curation, R.J.W.B., S.S. and T.P.; Writing-Original Draft Preparation, R.J.W.B.; Writing-Review \& Editing, R.J.W.B., S.C., S.S., J.S., J.B., D.F. and T.P.

Funding: This research was supported by the UK National Centre for Earth Observation, by the Simons Collaboration on Computational Biogeochemical Modeling of Marine Ecosystems/CBIOMES (Grant ID: 549947, SS), and by the Copernicus Marine Environment Monitoring Service (CMEMS) project "Optical data modelling and assimilation (OPTIMA)." CMEMS is implemented by MERCATOR OCEAN in the framework of a delegation agreement with the European Union. This work is also a contribution to the Ocean Colour Climate Change Initiative (OC-CCI) of the European Space Agency.

Acknowledgments: The authors thank all contributors to the NOMAD dataset for in situ data. The authors would like to acknowledge all scientists involved in the collection of the Bedford Institute of Oceanography data. We thank the NERC Earth Observation Data Acquisition and Analysis Service (NEODAAS) for support. We thank the editor and three anonymous reviewers for comments on our manuscript.

Conflicts of Interest: The authors declare no conflict of interest. 


\section{Appendix A. Ocean-Colour Model}

The case-1 ocean-colour model used to illustrate changes in the blue-to-green ratio of remote-sensing reflectance with changes in total chlorophyll (C) and SST is described in this Appendix.

\section{Appendix A.1. Remote-Sensing Reflectance}

The remote-sensing reflectance $\left(R_{r s}(\lambda)\right)$ was modelled as a function of the total absorption coefficient $(a(\lambda))$, total backscattering coefficient $\left(b_{b}(\lambda)\right)$, particulate backscattering coefficient $\left(b_{b p}(\lambda)\right)$, and pure seawater backscattering coefficient $\left(b_{b w}(\lambda)\right)$, according to Lee et al. [99]. The approach explicitly separates the phase-function of molecular and particle scattering, such that

$$
\begin{aligned}
R_{r s}(\lambda, \Omega)= & \left(M_{0}^{w}(\Omega)+M_{1}^{w}(\Omega) \frac{b_{b w}(\lambda)}{a(\lambda)+b_{b}(\lambda)}\right) \frac{b_{b w}(\lambda)}{a(\lambda)+b_{b}(\lambda)}+ \\
& \left(M_{0}^{p}(\Omega)+M_{1}^{p}(\Omega) \frac{b_{b p}(\lambda)}{a(\lambda)+b_{b}(\lambda)}\right) \frac{b_{b p}(\lambda)}{a(\lambda)+b_{b}(\lambda)^{\prime}}
\end{aligned}
$$

where parameters $M_{0}^{w}(\Omega), M_{1}^{w}(\Omega), M_{0}^{p}(\Omega), M_{1}^{p}(\Omega)$ were derived from Hydrolight simulations [99] for various Sun angles and viewing geometries, with $\Omega$ collectively representing these geometries. Parameters for solar zenith angle in air equal to zero, sensor nadir-view angle in air equal to zero, and a sensor azimuth angle in relation to the solar plane equal to zero were selected, such that $M_{0}^{w}=0.0604$, $M_{1}^{w}=0.0406, M_{0}^{p}=0.0402$ and $M_{1}^{p}=0.1310$ [99]. The term $b_{b w}(\lambda)$ was modelled from Zhang and $\mathrm{Hu}$ [100] and Zhang et al. [101], using SST as input and fixing salinity at $35 \mathrm{ppt}$.

\section{Appendix A.2. Backscattering Model}

The total backscattering coefficient $b_{b}(\lambda)$ was computed as

$$
b_{b}(\lambda)=b_{b w}(\lambda)+b_{b p}(\lambda)
$$

The particulate backscattering coefficient $\left(b_{b p}(\lambda)\right)$ was modelled as a function of the chlorophyll concentration of small $\left(C_{1,2}\right)$ and large $\left(C_{3,4}\right)$ phytoplankton following Brewin et al. [102], such that

$$
\begin{aligned}
b_{b p}(\lambda)= & b_{b p, 1,2}^{*}\left(\lambda_{0}\right)\left(\lambda / \lambda_{0}\right)^{-\gamma_{1,2}}\left\{C_{1,2}^{m}\left[1-\exp \left(-\frac{D_{1,2}}{C_{1,2}^{m}} C\right)\right]\right\}+ \\
& b_{b p, 3,4}^{*}\left(\lambda_{0}\right)\left(\lambda / \lambda_{0}\right)^{-\gamma_{3,4}}\left\{C-C_{1,2}^{m}\left[1-\exp \left(-\frac{D_{1,2}}{C_{1,2}^{m}} C\right)\right]\right\}+ \\
& b_{b p}^{k}\left(\lambda_{0}\right)\left(\lambda / \lambda_{0}\right)^{-\gamma_{k},}
\end{aligned}
$$

where $b_{b p, i}^{*}\left(\lambda_{0}\right)$ is the chlorophyll-specific backscattering coefficient for pico+nanophytoplankton $(i=1,2)$ and microphytoplankton $(i=3,4), b_{b p}^{k}\left(\lambda_{0}\right)$ represents the constant background component, $\gamma_{i}$ describes the spectral slope of backscattering for each phytoplankton group (i) and $\gamma_{k}$ the spectral slope of the constant background component. The reference wavelength $\left(\lambda_{0}\right)$ was set at $443 \mathrm{~nm}$. Parameters $C_{1,2}^{m}$ and $D_{1,2}$ were modelled as a function of SST using Equations (5) and (7), and parameters $b_{b p, i}^{*}\left(\lambda_{0}\right)$, $\gamma_{i}, b_{b p}^{k}\left(\lambda_{0}\right)$ and $\gamma_{k}$ were taken from Table 1 of Brewin et al. [102] (adjusting the reference wavelength $\left(\lambda_{0}\right)$ from $470 \mathrm{~nm}$ to $443 \mathrm{~nm}$ ).

\section{Appendix A.3. Absorption Model}

The total absorption coefficient $a(\lambda)$ was computed as

$$
a(\lambda)=a_{w}(\lambda)+a_{p h}(\lambda)+a_{d g}(\lambda)
$$

The absorption coefficient of pure seawater $\left(a_{w}(\lambda)\right)$ was taken from Pope and Fry [103]. The four-population model (Equations (2)-(10)) was used to compute $a_{p h}(\lambda)$ as a function of $C$ and 
SST. The absorption coefficient of combined detrital (non-algal) particles and CDOM $\left(a_{d g}(\lambda)\right)$ was modelled as

$$
a_{d g}(\lambda)=a_{d g}\left(\lambda_{0}\right) \exp \left[-S_{d g}\left(\lambda-\lambda_{0}\right)\right]
$$

where $S_{d g}$ is the slope of the exponential function, set to 0.018 [104], and $a_{d g}\left(\lambda_{0}\right)$, where $\lambda_{0}=443 \mathrm{~nm}$, was computed as a multiplicative factor of $a_{p h}\left(\lambda_{0}\right)$ following Sathyendranath et al. [10], such that $a_{d g}\left(\lambda_{0}\right)=0.3 a_{p h}\left(\lambda_{0}\right)$. Table A1 defines all symbols used in this manuscript.

Table A1. Symbols and definitions.

\begin{tabular}{|c|c|}
\hline Symbol & Definition \\
\hline$a$ & Total absorption coefficient $\left(\mathrm{m}^{-1}\right)$ \\
\hline$a^{*}$ & Chlorophyll-specific absorption coefficient of phytoplankton $\left(\mathrm{m}^{2}\left[\mathrm{mg} \mathrm{C}^{-1}\right)\right.$ \\
\hline$a_{i}^{*}$ & $\begin{array}{l}\text { Chlorophyll-specific absorption coefficient of phytoplankton group } i \text {, where } i \text { can be } 1,2,3 \text { or } 4 \\
\text { (pico-, nano-, dinoflagellates, or diatoms, respectively), or a combination of groups, for example, } \\
i=1,2 \text { would represent combined pico- and nano-phytoplankton }\left(\mathrm{m}^{2}\left[\mathrm{mg} \mathrm{C}^{-1}\right)\right.\end{array}$ \\
\hline$a_{d}$ & Absorption coefficient of detrital material $\left(\mathrm{m}^{-1}\right)$ \\
\hline$a_{d g}$ & Absorption coefficient of combined detrital particles and coloured dissolved organic matter $\left(\mathrm{m}^{-1}\right)$ \\
\hline$a_{p}$ & Absorption coefficient of particulate matter $\left(\mathrm{m}^{-1}\right)$ \\
\hline$a_{p h}$ & Absorption coefficient of phytoplankton $\left(\mathrm{m}^{-1}\right)$ \\
\hline$a_{p h, i}$ & $\begin{array}{l}\text { Absorption coefficient of phytoplankton group } i \text {, where } i \text { can be } 1,2,3 \text { or } 4 \text { (pico-, nano-, } \\
\text { dinoflagellates, or diatoms, respectively), or a combination of groups, for example, } i=1,2 \\
\text { would represent combined pico- and nano-phytoplankton }\left(\mathrm{m}^{-1}\right)\end{array}$ \\
\hline$a_{w}$ & Absorption coefficient of pure seawater $\left(\mathrm{m}^{-1}\right)$ \\
\hline$b_{b}$ & Total backscattering coefficient $\left(\mathrm{m}^{-1}\right)$ \\
\hline$b_{b p}$ & Backscattering coefficient of particulate matter $\left(\mathrm{m}^{-1}\right)$ \\
\hline$b_{b p, i}^{*}$ & $\begin{array}{l}\text { Chlorophyll-specific particulate backscattering coefficient of phytoplankton group } i \text {, where } i \text { can } \\
\text { be } 1,2,3 \text { or } 4 \text { (pico-, nano-, dinoflagellates, or diatoms, respectively), or a combination of groups, } \\
\text { for example, } i=1,2 \text { would represent combined pico- and nano-phytoplankton }\left(\mathrm{m}^{2}[\mathrm{mg} \mathrm{C}]^{-1}\right)\end{array}$ \\
\hline$b_{b p}^{k}$ & Constant background particulate backscattering coefficient $\left(\mathrm{m}^{-1}\right)$ \\
\hline$b_{b w}$ & Backscattering coefficient of pure seawater $\left(\mathrm{m}^{-1}\right)$ \\
\hline$C$ & Total chlorophyll concentration $\left(\mathrm{mg} \mathrm{m}^{-3}\right)$ \\
\hline$C_{i}$ & $\begin{array}{l}\text { Chlorophyll concentration for phytoplankton group } i \text {, where } i \text { can be } 1,2,3 \text { or } 4 \text { (pico-, nano-, } \\
\text { dinoflagellates, or diatoms, respectively), or a combination of groups, for example, } i=1,2 \\
\text { would represent combined pico- and nano-phytoplankton }\left(\mathrm{mg} \mathrm{m}^{-3}\right)\end{array}$ \\
\hline$C_{1,2}^{m}$ & Asymptotic maximum value of $C_{1,2}\left(\mathrm{mg} \mathrm{m}^{-3}\right)$ \\
\hline$C_{1}^{m}$ & Asymptotic maximum value of $C_{1}\left(\mathrm{mg} \mathrm{m}^{-3}\right)$ \\
\hline$D_{1,2}$ & $\begin{array}{l}\text { Fraction of total chlorophyll in combined pico-nanoplankton (cells }<20 \mu \mathrm{m} \text { ) as total chlorophyll } \\
\text { tends to zero }\end{array}$ \\
\hline$D_{1}$ & Fraction of total chlorophyll in picoplankton (cells $<2 \mu \mathrm{m}$ ) as total chlorophyll tends to zero \\
\hline$f_{a, i}$ & Relative uncertainty (or relative standard deviation) in $a_{p h, i}$ \\
\hline$f_{a, i}^{*}$ & Relative uncertainty (or relative standard deviation) in $a_{i}^{*}$ \\
\hline$f_{C, i}$ & Relative uncertainty (or relative standard deviation) in $C_{i}$ \\
\hline$F_{i}$ & $\begin{array}{l}\text { Fraction of total chlorophyll for phytoplankton group } i \text {, where } i \text { can be } 1,2,3 \text { or } 4 \text { (pico-, nano-, } \\
\text { dinoflagellates, or diatoms, respectively), or a combination of groups, for example, } i=1,2 \\
\text { would represent combined pico- and nano-phytoplankton }\end{array}$ \\
\hline$G_{i}$ & $\begin{array}{l}\text { Parameters for Equation (5) controlling changes in } C_{1,2}^{m} \text { with SST, where } i=a, b, c \text { or } d \text { depending } \\
\text { on parameter (see Table } 3 \text { ) }\end{array}$ \\
\hline
\end{tabular}


Table A1. Cont.

\begin{tabular}{|c|c|}
\hline Symbol & Definition \\
\hline$H_{i}$ & $\begin{array}{l}\text { Parameters for Equation (6) controlling changes in } C_{1}^{m} \text { with SST, where } i=a, b, c \text { or } d \text { depending } \\
\text { on parameter (see Table 3) }\end{array}$ \\
\hline$J_{i}$ & $\begin{array}{l}\text { Parameters for Equation (7) controlling changes in } D_{1,2} \text { with SST, where } i=a, b, c \text { or } d \text { depending } \\
\text { on parameter (see Table 3) }\end{array}$ \\
\hline$K_{i}$ & $\begin{array}{l}\text { Parameters for Equation (8) controlling changes in } D_{1} \text { with SST, where } i=a, b, c \text { or } d \text { depending } \\
\text { on parameter (see Table 3) }\end{array}$ \\
\hline$M_{0}^{w}$ & Parameter for the optical model of Lee et al. [99], see Equation (A1) \\
\hline$M_{1}^{w}$ & Parameter for the optical model of Lee et al. [99], see Equation (A1) \\
\hline$M_{0}^{p}$ & Parameter for the optical model of Lee et al. [99], see Equation (A1) \\
\hline$M_{1}^{p}$ & Parameter for the optical model of Lee et al. [99], see Equation (A1) \\
\hline$r$ & Pearson correlation coefficient \\
\hline$R_{r s}$ & Remote-sensing reflectance $\left(\mathrm{sr}^{-1}\right)$ \\
\hline$S_{d g}$ & Slope of an exponential function of $a_{d g}$ with $\lambda\left(\mathrm{nm}^{-1}\right)$ \\
\hline SST & Sea surface temperature $\left({ }^{\circ} \mathrm{C}\right)$ \\
\hline$\alpha$ & Parameter of Equation (9) controlling slope of change in $C_{3} / C_{3,4}$ with SST $\left({ }^{\circ} \mathrm{C}^{-1}\right)$ \\
\hline$\beta$ & Parameter of Equation (9) controlling the SST mid-point of $\alpha\left({ }^{\circ} \mathrm{C}\right)$ \\
\hline$\gamma_{i}$ & Spectral slope of $b_{b p, i}^{*}$ with $\lambda$ \\
\hline$\gamma_{k}$ & Spectral slope of $b_{b p}^{k}$ with $\lambda$ \\
\hline$\lambda$ & Wavelength of light (nm) \\
\hline$\lambda_{0}$ & Reference wavelength of light (set here to $443 \mathrm{~nm}$ ) \\
\hline$\Omega$ & $\begin{array}{l}\text { Collectively representing solar zenith angle, sensor nadir-view angle and sensor azimuth angle, } \\
\text { for the optical model of Lee et al. [99], see Equation (A1) }\end{array}$ \\
\hline$\Psi$ & Root mean square error \\
\hline
\end{tabular}

\section{References}

1. Sathyendranath, S.; Gouveia, A.D.; Shetye, S.R.; Ravindran, P.; Platt, T. Biological control of surface temperature in the Arabian Sea. Nature 1991, 349, 54-56. [CrossRef]

2. Sathyendranath, S.; Platt, T. Spectral effects in bio-optical control on the ocean system. Oceanologia 2007, 49, 5-39.

3. Kirk, J.T.O. A theoretical analysis of the contribution of algal cells to the attenuation of light within waters, I, General treatment of suspensions of living cells. New Phytol. 1975, 75, 1-20.

4. Morel, A. Available, usable, and stored radiant energy in relation to marine photosynthesis. Deep Sea Res. 1978, 25, 673-688. [CrossRef]

5. Morel, A. Optical modelling of the upper ocean in relation to its biogenous matter content (case I waters). J. Geophys. Res. 1988, 93, 10749-10768. [CrossRef]

6. Sathyendranath, S.; Platt, T. The spectral irradiance field at the surface and interior of the ocean: A model for applications in oceanography and remote sensing. J. Geophys. Res. 1988, 93, 9270-9280. [CrossRef]

7. Platt, T.; Jassby, A.D. Relationship between photosynthesis and light for natural assemblages of coastal marine-phytoplankton. J. Phycol. 1976, 12, 421-430. [CrossRef]

8. Kiefer, D.A.; Mitchell, B.G. A simple steady state description of phytoplankton growth based on absorption cross section and quantum efficiency. Limnol. Oceanogr. 1983, 27, 492-499. [CrossRef]

9. Platt, T.; Sathyendranath, S. Oceanic primary production: Estimation by remote sensing at local and regional Scales. Science 1988, 241, 1613-1620. [CrossRef]

10. Sathyendranath, S.; Stuart, V.; Cota, G.; Maas, H.; Platt, T. Remote sensing of phytoplankton pigments: A comparison of empirical and theoretical approaches. Int. J. Remote Sens. 2001, 22, 249-273. [CrossRef] 
11. Sathyendranath, S.; Watts, L.; Devred, E.; Platt, T.; Caverhill, C.; Maass, H. Discrimination of diatoms from other phytoplankton using ocean-colour data. Mar. Ecol. Prog. Ser. 2004, 272, 59-68. [CrossRef]

12. Ciotti, A.M.; Lewis, M.R.; Cullen, J.J. Assessment of the relationships between dominant cell size in natural phytoplankton communities and the spectral shape of the absorption coefficient. Limnol. Oceanogr. 2002, 47, 404-417. [CrossRef]

13. Roy, S.; Sathyendranath, S.; Platt, T. Retrieval of phytoplankton size from bio-optical measurements: Theory and applications. J. R. Soc. Interface 2010, 8, 650-660. [CrossRef] [PubMed]

14. Devred, E.; Sathyendranath, S.; Stuart, V.; Platt, T. A three component classification of phytoplankton absorption spectra: Applications to ocean-colour data. Remote Sens. Environ. 2011, 115, 2255-2266. [CrossRef]

15. Dall'Olmo, G.; Boss, E.; Behrenfeld, M.; Westberry, T.K. Particulate optical scattering coefficients along an Atlantic Meridional Transect. Opt. Express 2012, 20, 21532-21551. [CrossRef] [PubMed]

16. Organelli, E.; Bricaud, A.; Antoine, D.; Uitz, J. Multivariate approach for the retrieval of phytoplankton size structure from measured light absorption spectra in the Mediterranean Sea (BOUSSOLE site). Appl. Opt. 2013, 52, 2257-2273. [CrossRef]

17. Kirk, J.T.O. A theoretical analysis of the contribution of algal cells to the attenuation of light within waters, II, Spherical cells. New Phytol. 1975, 75, 21-36. [CrossRef]

18. Morel, A.; Bricaud, A. Theoretical results concerning light absorption in a discrete medium, and application to specific absorption of phytoplankton. Deep-Sea Res. 1981, 28, 1375-1393. [CrossRef]

19. Sathyendranath, S.; Lazzara, L.; Prieur, L. Variations in the spectral values of specific absorption of phytoplankton. Limnol. Oceanogr. 1987, 32, 403-415. [CrossRef]

20. Hoepffner, N.; Sathyendranath, S. Effect of pigment composition on absorption properties of phytoplankton. Mar. Ecol. Prog. Ser. 1991, 73, 11-23. [CrossRef]

21. Lohrenz, S.E.; Weidemann, A.D.; Tuel, M. Phytoplankton spectral absorption as influenced by community size structure and pigment composition. J. Plankton Res. 2003, 25, 35-61. [CrossRef]

22. Bricaud, A.; Claustre, H.; Ras, J.; Oubelkheir, K. Natural variability of phytoplanktonic absorption in oceanic waters: Influence of the size structure of algal populations. J. Geophys. Res. 2004, 109, C11010. [CrossRef]

23. Bricaud, A.; Babin, M.; Morel, A.; Claustre, H. Variability in the chlorophyll specific absorption coefficients of natural phytoplankton: Analysis and parameterization. J. Geophys. Res. 1995, 100, 13321-13332. [CrossRef]

24. Prieur, L.; Sathyendranath, S. An optical classification of coastal and oceanic waters based on the specific spectral absorption curves of phytoplankton pigments, dissolved organic matter and other particulate materials. Limnol. Oceanogr. 1981, 26, 617-689. [CrossRef]

25. Yentch, C.; Phinney, D. A bridge between ocean optics and microbial ecology. Limnol. Oceanogr. 1989, 34, 1694-1705. [CrossRef]

26. Morel, A. Light and marine photosynthesis: A spectral model with geochemical and climatological implications. Prog. Oceanogr. 1991, 26, 263-306. [CrossRef]

27. Bricaud, A.; Morel, A.; Babin, M.; Allali, K.; Claustre, H. Variations of light absorption by suspended particles with the chlorophyll a concentration in oceanic (case 1) waters: Analysis and implications for bio-optical models. J. Geophys. Res. 1998, 103, 31033-31044. [CrossRef]

28. Carder, K.L.; Hawes, S.K.; Baker, K.A.; Smith, R.C.; Steward, R.G.; Mitchell, B.G. Reflectance model for quantifying chlorophyll a in the presence of productivity degradation products. J. Geophys. Res. 1991, 96, 20599-20611. [CrossRef]

29. Cleveland, J.S. Regional models for phytoplankton absorption as a function of chlorophyll a concentration. J. Geophys. Res. Ocean. 1995, 100, 13333-13344. [CrossRef]

30. Lutz, V.A.; Sathyendranath, S.; Head, E.J.H. Absorption coefficient of phytoplankton: Regional variations in the North Atlantic. Mar. Ecol. Prog. Ser. 1996, 135, 197-213. [CrossRef]

31. Brewin, R.J.W.; Devred, E.; Sathyendranath, S.; Hardman-Mountford, N.J.; Lavender, S.J. Model of phytoplankton absorption based on three size classes. Appl. Opt. 2011, 50, 4535-4549. [CrossRef]

32. Devred, E.; Sathyendranath, S.; Stuart, V.; Maas, H.; Ulloa, O.; Platt, T. A two-component model of phytoplankton absorption in the open ocean: Theory and applications. J. Geophys. Res. 2006, 111, C03011. [CrossRef]

33. Uitz, J.; Huot, Y.; Bruyant, F.; Babin, M.; Claustre, H. Relating phytoplankton photophysiological properties to community structure on large scales. Limnol. Oceanogr. 2008, 53, 614-630. [CrossRef] 
34. Brewin, R.J.W.; Sathyendranath, S.; Hirata, T.; Lavender, S.J.; Barciela, R.; Hardman-Mountford, N.J. A three-component model of phytoplankton size class for the Atlantic Ocean. Ecol. Model. 2010, 221, 1472-1483. [CrossRef]

35. Kamykowski, D.; Zentara, S.J. Can phytoplankton community structure be inferred from satellite-derived sea surface temperature anomalies calculated relative to nitrate depletion temperatures? Remote Sens. Environ. 2003, 86, 444-457. [CrossRef]

36. Raitsos, D.E.; Lavender, S.J.; Maravelias, C.D.; Haralambous, J.; Richardson, A.J.; Reid, P.C. Identifying four phytoplankton functional types from space: An ecological approach. Limnol. Oceanogr. 2008, 53, 605-613. [CrossRef]

37. Feng, Y.; Hare, C.E.; Leblanc, K.; Rose, J.M.; Zhang, Y.; DiTullio, G.R.; Lee, P.A.; Wilhelm, S.W.; Rowe, J.M.; Sun, J.; et al. Effects of increased $\mathrm{pCO}_{2}$ and temperature on the North Atlantic spring bloom. I. The phytoplankton community and biogeochemical response. Mar. Ecol. Prog. Ser. 2009, 388, 13-25. [CrossRef]

38. Morán, X.A.G.; López-Urrutia, A.; Calvo-Díaz, A.; Li, W.K.W. Increasing importance of small phytoplankton in a warmer ocean. Glob. Chang. Biol. 2010, 16, 1137-1144. [CrossRef]

39. Barnes, C.; Irigoien, X.; De Oliveira, J.A.A.; Maxwell, D.; Jennings, S. Predicting marine phytoplankton community size structure from empirical relationships with remotely sensed variables. J. Plankton Res. 2011, 33, 13-24. [CrossRef]

40. Hilligsøe, K.M.; Richardson, K.; Bendtsen, J.; Sørensen, L.L.; Nielsen, T.G.; Lyngsgaard, M.M. Linking phytoplankton community size composition with temperature, plankton food web structure and sea-air $\mathrm{CO}_{2}$ flux. Deep Sea Res. Part I Oceanogr. Res. Pap. 2011, 58, 826-838. [CrossRef]

41. Flombaum, P.; Gallegos, J.L.; Gordillo, R.A.; Rincón, J.; Zabala, L.L.; Jiao, N.; Karl, D.M.; Li, W.; Lomas, M.; Veneziano, D.; et al. Present and future global distributions of the marine Cyanobacteria Prochlorococcus synechococcus. Proc. Natl. Acad. Sci. USA 2013, 110, 9824-9829. [CrossRef] [PubMed]

42. Mousing, E.A.; Ellegaard, M.; Richardson, K. Global patterns in phytoplankton community size structure-evidence for a direct temperature effect. Mar. Ecol. Prog. Ser. 2014, 496, 25-38. [CrossRef]

43. Lange, P.; Brewin, R.J.W.; Dall'Olmo, G.; Tarran, G.; Sathyendranath, S.; Zubkov, M.; Bouman, H. Scratching beneath the surface: A model to predict the vertical distribution of Prochlorococcus Using Remote Sensing. Remote Sens. 2018, 10, 847. [CrossRef]

44. Agusti, S.; Lubián, L.M.; Morerno-Ostos, E.; Estrada, M.; Duarte, C.M. Projected Changes in Photosynthetic Picoplankton in a Warmer Subtropical Ocean. Front. Mar. Sci. 2019, 5, 506. [CrossRef]

45. Bouman, H.A.; Platt, T.; Sathyendranath, S.; Li, W.K.; Stuart, V.; Fuentes-Yaco, C.; Maass, H.; Horne, E.P.; Ulloa, O.; Lutz, V.; et al. Temperature as indicator of optical properties and community structure of marine phytoplankton: Implications for remote sensing. Mar. Ecol. Prog. Ser. 2003, 258, 19-30. [CrossRef]

46. Brewin, R.J.W.; Ciavatta, S.; Sathyendranath, S.; Jackson, T.; Tilstone, G.; Curran, K.; Airs, R.; Cummings, D.; Brotas, V.; Organelli, E.; et al. Uncertainty in ocean-color estimates of chlorophyll for phytoplankton groups. Front. Mar. Sci. 2017, 4, 104. [CrossRef]

47. Ciavatta, S.; Brewin, R.J.W.; Skákala, J.; Polimene, L.; de Mora, L.; Artioli, Y.; Allen, J.I. Assimilation of ocean-color plankton functional types to improve marine ecosystem simulations. J. Geophys. Res. Ocean. 2018, 123, 834-854. [CrossRef]

48. Skákala, J.; Ford, D.; Brewin, R.J.W.; McEwan, R.; Kay, S.; Taylor, B.; de Mora, L.; Ciavatta, S. The assimilation of phytoplankton functional types for operational forecasting in the northwest European shelf. J. Geophys. Res. Ocean. 2018, 123, 5230-5247. [CrossRef]

49. Ciavatta, S.; Torres, R.; Martinez-Vicente, V.; Smyth, T.; Dall'Olmo, G.; Polimene, L.; Allen, J.I. Assimilation of remotely-sensed optical properties to improve marine biogeochemistry modelling. Prog. Oceanogr. 2014, 127, 74-95. [CrossRef]

50. Ducklow, H.W.; Harris, R.P. Introduction to the JGOFS North Atlantic bloom experiment. Deep Sea Res. Part II Top. Stud. Oceanogr. 1993, 40,1-8. [CrossRef]

51. Holt, J.; Allen, J.I.; Anderson, T.R.; Brewin, R.J.W.; Butenschön, M.; Harle, J.; Huse, G.; Lehodey, P.; Lindemann, C.; Memery, L.; et al. Challenges in integrative approaches to modelling the marine ecosystems of the North Atlantic: Physics to fish and coasts to ocean. Prog. Oceanogr. 2014, 129, 285-313. [CrossRef]

52. Werdell, P.J.; Bailey, S.W. An improved in-situ bio-optical data set for ocean colour algorithm development and satellite data production validation. Remote Sens. Environ. 2005, 98, 122-140. [CrossRef] 
53. Werdell, P.J. Global bio-optical algorithms for ocean color satellite applications. EOS Trans. AGU 2009, 90, 4. [CrossRef]

54. De Boyer Montégut, C.; Madec, G.; Fisher, A.S.; Lazar, A.; Iudicone, D. Mixed layer depth over the global ocean: An examination of profile data and a profile-based climatology. J. Geophys. Res. 2004, 109, C12003. [CrossRef]

55. Reynolds, R.W.; Smith, T.M.; Liu, C.; Chelton, D.B.; Casey, K.S.; Schlax, M.G. Daily high-resolution-blended analysis for sea surface temperature. J. Clim. 2007, 20, 5473-5496. [CrossRef]

56. Moré, J. The Levenberg-Marquardt algorithm: Implementation and theory. In Numerical Analysis; Springer: Berlin, Germany, 1978; p. 105.

57. Markwardt, C.B. Non-linear least squares fitting in IDL with MPFIT. In Proceedings of the Astronomical Data Analysis Software and Systems XVIII, ASP Conference Series, Quebec City, QC, Canada, 2-5 November 2008; Bohlender, D., Dowler, P., Duran, D., Eds.; Astronomical Society of the Pacific: San Francisco, CA, USA, 2008; Volume 411.

58. Efron, B. Bootstrap methods: Another look at the jackknife. Ann. Stat. 1979, 7, 1-26. [CrossRef]

59. Brewin, R.J.W.; Sathyendranath, S.; Jackson, T.; Barlow, R.; Brotas, V.; Airs, R.; Lamont, T. Influence of light in the mixed layer on the parameters of a three-component model of phytoplankton size structure. Remote Sens. Environ. 2015, 168, 437-450. [CrossRef]

60. Campbell, J.W. The lognormal distribution as a model for bio-optical variability in the sea. J. Geophys. Res. 1995, 100, 13237-13254. [CrossRef]

61. Jackson, T.; Sathyendranath, S.; Mélin, F. An improved optical classification scheme for the Ocean Colour Essential Climate Variable and its applications. Remote Sens. Environ. 2017, 203, 152-161. [CrossRef]

62. Ciavatta, S.; Kay, S.; Saux-Picart, S.; Butenschön, M.; Allen, J.I. Decadal reanalysis of biogeochemical indicators and fluxes in the North West European shelf-sea ecosystem. J. Geophys. Res. 2016, 121, 1824-1845. [CrossRef]

63. Duysens, L.N.M. The flattening of the absorption spectrum of suspensions as compared to that of solutions. Biochim. Biophys. Acta 1956, 19, 1-12. [CrossRef]

64. Organelli, E.; Nuccio, C.; Lazzara, L.; Uitz, J.; Bricaud, A.; Massi, L. On the discrimination of multiple phytoplankton groups from light absorption spectra of assemblages with mixed taxonomic composition and variable light conditions. Appl. Opt. 2017, 56, 3952-3968. [CrossRef]

65. Ciotti, A.M.; Bricaud, A. Retrievals of a size parameter for phytoplankton and spectral light absorption by coloured detrital matter from water-leaving radiances at SeaWiFS channels in a continental shelf off Brazil. Limnol. Oceanogr. Methods 2006, 4, 237-253. [CrossRef]

66. Barlow, R.G.; Aiken, J.; Holligan, P.M.; Cummings, D.G.; Mariotena, S.; Hooker, S. Phytoplankton pigment and absorption characteristics along meridional transects in the Atlantic Ocean. Deep-Sea Res. I 2002, 49, 637-660. [CrossRef]

67. Partensky, F.; Hoepffner, N.; Li, W.K.W.; Ulloa, O.; Vaulot, D. Photoacclimation of Prochlorococcus sp. (Prochlorophyta) strains isolated from the North Atlantic and the Mediterranean Sea. Plant Physiol. 1993, 101, 285-296. [CrossRef]

68. Morel, A.; Ahn, Y.H.; Partensky, F.; Vaulot, D.; Claustre, H. Prochlorococcus Synechococcus: A comparitive study of thier optical properties in relation to thier size and pigmentation. J. Mar. Res. 1993, 51, 617-649. [CrossRef]

69. Moore, L.R.; Goericke, R.; Chisholm, S.W. Comparative physiology of Synechococcus and Prochlorococcus: Influence of light and temperature on growth, pigments, fluorescence and absorptive properties. Mar. Ecol. Prog. Ser. 1995, 116, 259-275. [CrossRef]

70. Liu, H.; Probert, I.; Uitz, J.; Claustre, H.; Aris-Brosou, S.; Frada, M.; Not, F.; de Vargas, C. Extreme diversity in noncalcifying haptophytes explains a major pigment paradox in open oceans. Proc. Natl. Acad. Sci. USA 2009, 106, 12803-12808. [CrossRef]

71. Johnsen, G.; Nelson, N.B.; Jovine, R.V.M.; Prézelin, B.B. Chromoprotein- and pigment-dependent modelling of spectral light absorption in two dinoflagellates, Prorocentrum minimum and Heterocapsa pygmaea. Mar. Ecol. Prog. Ser. 1994, 114, 245-258. [CrossRef]

72. Finkel, Z.V. Light absorption and size scaling of light-limited metabolism in marine diatoms. Limnol. Oceanogr. 2001, 38, 679-687. [CrossRef] 
73. Hirata, T.; Aiken, J.; Hardman-Mountford, N.J.; Smyth, T.J.; Barlow, R.G. An absorption model to derive phytoplankton size classes from satellite ocean colour. Remote Sens. Environ. 2008, 112, 3153-3159. [CrossRef]

74. Werdell, P.J.; Franz, B.A.; Bailey, S.W.; Feldman, G.C.; Boss, E.; Brando, V.E.; Dowell, M.; Hirata, T.; Lavender, S.J.; Lee, Z.; et al. Generalized ocean color inversion model for retrieving marine inherent optical properties. Appl. Opt. 2013, 52, 2019-2037. [CrossRef]

75. IOCCG. Inherent Optical Property Measurements and Protocols: Absorption Coefficient. In IOCCG Ocean Optics and Biogeochemistry Protocols for Satellite Ocean Colour Sensor Validation; Neeley, A.R., Mannino, A., Eds.; IOCCG: Dartmouth, NS, Canada, 2018; Volume 1.

76. Brewin, R.J.W.; Sathyendranath, S.; Müller, D.; Brockmann, C.; Deschamps, P.Y.; Devred, E.; Doerffer, R.; Fomferra, N.; Franz, B.A.; Grant, M.; et al. The Ocean Colour Climate Change Initiative: III. A round-robin comparison on in-water bio-optical algorithms. Remote Sens. Environ. 2015, 162, 271-294. [CrossRef]

77. Marañón, E.; Cermeño, P.; Latasa, M.; Tadonléké, R.D. Temperature, resources, and phytoplankton size structure in the ocean. Limnol. Oceanogr. 2012, 57, 1266-1278. [CrossRef]

78. López-Urrutia, A.; Morán, X.A.G. Temperature affects the size-structure of phytoplankton communities in the ocean. Limnol. Oceanogr. 2015, 60, 733-738. [CrossRef]

79. Marañón, E.; Cermeno, P.; Latasa, M.; Tadonléké, R.D. Resource supply alone explains the variability of marine phytoplankton size structure. Limnol. Oceanogr. 2015, 60, 1848-1854. [CrossRef]

80. Eppley, R.W. Temperature and phytoplankton growth in the sea. Fish. Bull. 1972, 70, 1063-1085.

81. Aksnes, D.L.; Egge, J.K. A theoretical-model for nutrient-uptake in phytoplankton. Mar. Ecol. Prog. Ser. 1991, 70, 65-72. [CrossRef]

82. Toseland, A.; Daines, S.J.; Clark, J.R.; Kirkham, A.; Strauss, J.; Uhlig, C.; Lenton, T.M.; Valentin, K.; Pearson, G.A.; Moulton, V.; et al. The impact of temperature on marine phytoplankton resource allocation and metabolism. Nat. Clim. Chang. 2013, 3, 979-984. [CrossRef]

83. Brewin, R.J.W.; Sathyendranath, S.; Tilstone, G.; Lange, P.K.; Platt, T. A multicomponent model of phytoplankton size structure. J. Geophys. Res. Ocean. 2014, 119, 3478-3496. [CrossRef]

84. López-Urrutia, A. The metabolic theory of ecology and algal bloom formation. Limnol. Oceanogr. 2008, 53, 2046-2047. [CrossRef]

85. Sathyendranath, S.; Platt, T.; Horne, E.P.; Harrison, W.G.; Ulloa, O.; Outerbridge, R.; Hoepffner, N. Estimation of new production in the ocean by compound remote sensing. Nature 1991, 353, 129-133. [CrossRef]

86. Ward, B.A. Temperature-correlated changes in phytoplankton community structure are restricted to polar waters. PLoS ONE 2015, 10, e0135581. [CrossRef]

87. Brewin, R.J.W.; Morán, X.A.G.; Raitsos, D.E.; Gittings, J.A.; Calleja, M.L.; Viegas, M.S.; Ansari, M.I.; Al-Otaibi, N.; Huete-Stauffer, T.M.; Hoteit, I. Factors regulating the relationship between total and size-fractionated chlorophyll-a in coastal waters of the Red Sea. Front. Microbiol. 2019, 10, 1964. [CrossRef]

88. O'Reilly, J.E.; Maritorena, S.; Mitchell, B.G.; Siegel, D.A.; Carder, K.L.; Garver, S.A.; Kahru, M.; McClain, C. Ocean chlorophyll algorithms for SeaWiFS. J. Geophys. Res. 1998, 103, 24937-24953. [CrossRef]

89. NASA. Ocean Color Chlorophyll (OC) v6. 2010. Available online: http://oceancolor.gsfc.nasa.gov/ REPROCESSING/R2009/ocv6/ (accessed on 25 September 2019).

90. Gregg, W.W.; Casey, N.W. Global and regional evaluation of the SeaWiFS chlorophyll data set. Remote Sens. Environ. 2004, 93, 463-479. [CrossRef]

91. Johnson, R.; Strutton, P.G.; Wright, S.W.; McMinn, A.; Meiners, K.M. Three improved satellite chlorophyll algorithms for the Southern Ocean. J. Geophys. Res. Ocean. 2013, 118, 3694-3703. [CrossRef]

92. Jena, B. The effect of phytoplankton pigment composition and packaging on the retrieval of chlorophyll-a concentration from satellite observations in the Southern Ocean. Int. J. Remote Sens. 2017, 38, 3763-3784. [CrossRef]

93. Christensen, J.H.; Hewitson, B.; Busuioc, A.; Chen, A.; Gao, X.; Held, I.; Jones, R.; Kolli, R.K.; Kwon, W.T.; Laprise, R.; et al. Regional Climate Projections. In Climate Change 2007: The Physical Science Basis. Contribution of Working Group I to the Fourth Assessment Report of the Intergovernmental Panel on Climate; Solomon, S., Qin, D., Manning, M., Chen, Z., Marquis, M., Averyt, K.B., Tignor, M., Miller, H.L., Eds.; Cambridge University Press: Cambridge, UK; New York, NY, USA, 2007.

94. Dutkiewicz, S.; Hickman, A.E.; Jahn, O.; Henson, S.; Beaulieu, C.; Monier, E. Ocean colour signature of climate change. Nat. Commun. 2019, 10,1-13. [CrossRef] 
95. Brewin, R.J.W.; Dall'Olmo, G.; Pardo, S.; van Dongen-Vogel, V.; Boss, E.S. Underway spectrophotometry along the Atlantic Meridional Transect reveals high performance in satellite chlorophyll retrievals. Remote Sens. Environ. 2016, 183, 82-97. [CrossRef]

96. Gregg, W.W.; Rousseaux, C.S. Directional and spectral irradiance in ocean models: Effects on simulated global phytoplankton, nutrients, and primary production. Front. Mar. Sci. 2016, 3, 240. [CrossRef]

97. Shulman, I.; Frolov, S.; Anderson, S.; Penta, B.; Gould, R.; Sakalaukus, P.; Ladner, S. Impact of bio-optical data assimilation on short-term coupled physical, bio-optical model predictions. J. Geophys. Res. Ocean. 2013, 118, 2215-2230. [CrossRef]

98. Jones, E.M.; Baird, M.E.; Mongin, M.; Parslow, J.; Skerratt, J.; Lovell, J.; Margvelashvili, N.; Matear, R.J.; Wild-Allen, K.; Robson, B.; et al. Use of remote-sensing reflectance to constrain a data assimilating marine biogeochemical model of the Great Barrier Reef. Biogeosciences 2016, 13, 6441-6469. [CrossRef]

99. Lee, Z.P.; Du, K.; Voss, K.J.; Zibordi, G.; Lubac, B.; Arnone, R.; Weidemann, A. An inherent-opticalproperty-centered approach to correct the angular effects in water-leaving radiance. Appl. Opt. 2011, 50, 3155-3167. [CrossRef]

100. Zhang, X.; Hu, L. Estimating scattering of pure water from density fluctuation of the refractive index. Opt. Express 2009, 17, 1671-1678. [CrossRef]

101. Zhang, X.; Hu, L.; He, M.X. Scattering by pure seawater: Effect of salinity. Opt. Express 2009, 17, 5698-5710. [CrossRef]

102. Brewin, R.J.W.; Dall'Olmo, G.; Sathyendranath, S.; Hardman-Mountford, N.J. Particle backscattering as a function of chlorophyll and phytoplankton size structure in the open-ocean. Opt. Express 2012, 20, 17632-17652. [CrossRef]

103. Pope, R.; Fry, E. Absorption spectrum $(380-700 \mathrm{~nm})$ of pure water. II. Integrating cavity measurements. Appl. Opt. 1997, 36, 8710-8723. [CrossRef]

104. Morel, A.; Gentili, B. A simple band ratio technique to quantify the colored dissolved and detrital organic material from ocean color remotely sensed data. Remote Sens. Environ. 2009, 113, 998-1011. [CrossRef]

(C) 2019 by the authors. Licensee MDPI, Basel, Switzerland. This article is an open access article distributed under the terms and conditions of the Creative Commons Attribution (CC BY) license (http:/ / creativecommons.org/licenses/by/4.0/). 